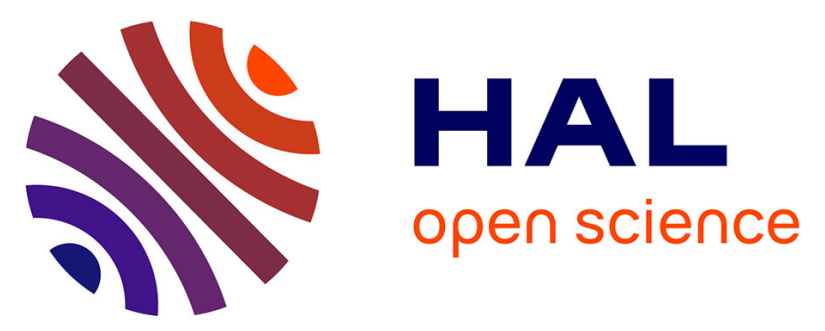

\title{
Oroclinal buckling and associated lithospheric-scale material flow - insights from physical modelling: Implication for the Mongol-Hingan orocline
}

Ondřej Krýza, Ondrej Lexa, Karel Schulmann, Alexandra Guy, Denis Gapais, John Cosgrove, Wenjiao Xiao

\section{To cite this version:}

Ondřej Krýza, Ondrej Lexa, Karel Schulmann, Alexandra Guy, Denis Gapais, et al.. Oroclinal buckling and associated lithospheric-scale material flow - insights from physical modelling: Implication for the Mongol-Hingan orocline. Tectonophysics, 2021, 800, pp.228712. 10.1016/j.tecto.2020.228712 . insu03093666

\section{HAL Id: insu-03093666 \\ https://hal-insu.archives-ouvertes.fr/insu-03093666}

Submitted on 4 Jan 2021

HAL is a multi-disciplinary open access archive for the deposit and dissemination of scientific research documents, whether they are published or not. The documents may come from teaching and research institutions in France or abroad, or from public or private research centers.
L'archive ouverte pluridisciplinaire HAL, est destinée au dépôt et à la diffusion de documents scientifiques de niveau recherche, publiés ou non, émanant des établissements d'enseignement et de recherche français ou étrangers, des laboratoires publics ou privés. 


\section{Journal Pre-proof}

Oroclinal buckling and associated lithospheric-scale material flow - insights from physical modelling: Implication for the MongolHingan orocline

Ondřej Krýza, Ondrej Lexa, Karel Schulmann, Alexandra Guy, Denis Gapais, John Cosgrove, Wenjiao Xiao

PII: S0040-1951(20)30395-4

DOI: https://doi.org/10.1016/j.tecto.2020.228712

Reference: TECTO 228712

To appear in: Tectonophysics

Received date: 19 March 2020

Revised date: 9 November 2020

Accepted date:

Please cite this article as: O. Krýza, O. Lexa, K. Schulmann, et al., Oroclinal buckling and associated lithospheric-scale material flow - insights from physical modelling: Implication for the Mongol-Hingan orocline, Tectonophysics (2020), https://doi.org/10.1016/ j.tecto.2020.228712

This is a PDF file of an article that has undergone enhancements after acceptance, such as the addition of a cover page and metadata, and formatting for readability, but it is not yet the definitive version of record. This version will undergo additional copyediting, typesetting and review before it is published in its final form, but we are providing this version to give early visibility of the article. Please note that, during the production process, errors may be discovered which could affect the content, and all legal disclaimers that apply to the journal pertain.

(C) 2020 Published by Elsevier. 


\section{Oroclinal buckling and associated lithospheric-scale material flow - insights from physical modelling: implication for the Mongol-Hingan orocline}

Ondřej Krýza ${ }^{1,2}$, Ondrej Lexa ${ }^{1}$, Karel Schulmann ${ }^{3,4}$, Alexandra Guy ${ }^{3}$, Denis Gapais ${ }^{5}$, John Cosgrove $^{6}$ and Wenjiao Xiao ${ }^{7,8,9}$

${ }^{1}$ Institute of Petrology and Structural Geology, Charles University, Albertov 6, 128 43, Czech Republic ${ }^{2}$ Institute of Geophysics, Czech Academy of Sciences, Boční II/1401, Prague 4, 141 31, Czech Republic

${ }^{3}$ Czech Geological Survey, Center for Lithosphere Research, Klárov 3, 11821 Prague 1, Czech Republic

${ }^{4}$ Institut de Physique du Globe de Strasbourg - CNRS UMR7516, Université de Strasbourg, France

${ }^{5}$ Géosciences Rennes, UMR 6118 CNRS, Université de Rennes 1, 35042 Rennes cedex, France

${ }^{6}$ Department of Earth Sciences and Engineering, Imperial College London, Prince Consort Road, SW7 2AZ, UK

${ }^{7}$ Xinjiang Research Center for Mineral Resources, Xinjiang Institute of Ecology and Geography, Chinese Academy of Sciences, Urumqi, Xinjiang 830011, China

${ }^{8}$ College of Earth and Planetary Sciences, University of Chinese Academy of Sciences, Beijing 100049, China

${ }^{9}$ State Key Laboratory of Lithospheric Evolution, Institute of Geology and ('esphysics, Chinese Academy of Sciences, 100029 Beijing, China

Corresponding author: Ondřej Krýza (kryza@ natur.cuni.cz)

\section{Key Points:}

- Oroclinal buckling model of a vertical belt ser ar a ting horizontally stratified domains

- Early buckling stage shows a characteristic of : nd ntation tectonics

- Orocline amplification causes a large-scale v srtex flow around an inflection line 


\begin{abstract}
We present a new analogue model of oroclinal buckling, which is based on recent advances in our geological understanding of the Mongolian orocline in the Central Asian Orogenic Belt. The model simulates an amplification of a preexisting, gently arcuated accretionary system. In the analogue models, we established three neighboring subdomains that represent contrasting lithospheric domains separated by a steep "subduction" interface. The shortening of the model is parallel to the pseudo-linear interface between these subdomains and produces two different deformation patterns in the amplified interlimb areas of the orocline. We used analogue modelling techniques to investigate both the flow of a ductile lithosphere and the brittle deformation of an upper crust that is associated with the development of an orocline. The modelling results show that: (1) two types of regional-scale folds develop both of which are upright. The largest are steeply plunging oroclines and the smaller have subhorizontal axes; (2) the overall deformation distri'ution displays significant thickening/thinning and exhumation of the lower ductile layers with variations of upward transfer of crustal material; (3) the hinge regions of the two a ljac nt oroclines studied consist of different materials, one contains oceanic and the othe: tcivic lower crustal rocks. It is found that the geometry of the lithosphere beneath the $\mathrm{t}_{\mathrm{V}} \mathrm{\rho} \mathrm{r}$ gions is very different; (4) the geometry of the orocline is non-cylindrical and exhib ${ }^{-}$an increasing plunge of fold axes when traced from the upper-crust to deeper lithosphe $1 \mathrm{c} 1$ 'yers. The resulting model is used to geophysically constrain deep crustal structures and sur - - e deformation patterns in Mongolia.
\end{abstract}

Keywords: Analogue modelling, Mongolian rou:ie, Hingan orocline, oroclinal buckling

\title{
1 Introduction
}

The concept of orocline formation $w$ 's lescribed almost seventy years ago by Carey (1955) as a product of secondary curvat ire t the originally linear orogen. The secondary curvature results from either passive oro lina' bending (e.g. Rosenbaum and Lister, 2004; Rosenbaum, 2012; Menant et al., 2016), a ${ }^{-t i v}$ oroclinal bending or oroclinal buckling (Edel et al., 2014; Lehmann et al., 2010; Ros nbcum, 2014). The passive bending mode is controlled by the geometry of the subdur ${ } n_{\varepsilon}$ plate such as curvatures produced by variations in rollback velocity. In contrast, the ctive oroclinal bending is controlled by horizontal indentation perpendicular to the suba iction/accretionary orogen (e.g. the entry of an oceanic plateau or a continental block into a subduction zone), while oroclinal buckling results from buckling instability during the orogen-parallel shortening of a linear orogenic belt. The latter mechanism is commonly related to the advance of continental blocks parallel to the belt as exemplified by the Paleozoic Iberian, Kazakhstan and Mongolian oroclines (Pastor-Galán et al. 2012; Sengör et al., 1993; Lehmann et al., 2010). Various aspects such as paleomagnetism, structural evolution and sedimentary records as well as mechanical processes related to orogen-parallel shortening are best-described and understood for the Iberian orocline (Gutiérrez-Alonso et al., 2012; Johnston et al., 2013; Weil et al., 2013; Shaw et al., 2015; Shaw and Johnston, 2016a, 2016b). In contrast, processes associated with the formation of the Kazakhstan and Mongolian oroclinal systems are less constrained and consequently, mechanisms of orogen-parallel shortening of those two systems remain poorly understood. These oroclines constitute a major part of the 13,000 km long Central Asian Orogenic Belt (CAOB), which formed from Neo-Proterozoic to Mesozoic times (Şengör et al., 1993; Wilhem et al., 2012). Both oroclines are composed of Precambrian ribbon 
continents surrounded by wide accretionary complexes and magmatic arcs (Fig. 1). Their origin has recently been hotly debated and suggestions include the buckling and strike-slip imbrication of two Late Proterozoic to Early Paleozoic intra-oceanic arcs (Şengör et al., 1993; Şengör and Natal'in, 1996), the passive oroclinal bending related to the continuous roll-back of the Paleoasian ocean (Xiao et al., 2018) and the pure buckling of a long ribbonlike system (Lehmann et al., 2010). While the tectonic evolution of the Kazakhstan system remains poorly constrained, recent investigations of the Mongolian orocline have allowed its deep crustal structure to be defined (Guy et al., 2014; 2015; 2020) and the global architecture of the whole system prior its orogen-parallel shortening to be determined (Jiang et al., 2016; 2017). A new model of buckling of the whole linear system has been proposed (Lehmann et al., 2010; Guy et al., 2020) and detailed structural investigations showing geochronologically constrained orthogonal superposition of deformation fabrics, have been presented (e.g. Lehmann et al., 2010; Guy et al., 2014; Zhang et al., 2015; Jiang et al., 2019)

In addition, Yakubchuk $(2004 ; 2008)$ proposed that the whole region between the Siberian and North China cratons can be defined by a double oroc'illa' ${ }^{\prime}$ lold based on the arcuate distribution of basement blocks which connect Precambrian, iht ons in Mongolia with those in the far-east of China (Fig. 1a). This author thus defines he ${ }_{1}$ Iongolian orocline in the north and the Hingan orocline in the SE, both cored by Palec 'oic uceanic units. Later, Yakubchuk (2017) proposed a plate-tectonic scenario explain' is a kinematic model related to the formation of this full wavelength oroclinal bend a rirg Late Paleozoic amalgamation of Pangea. Based on Yakubchuk's approach, we used tie IL GS geological map (Parfenov et al., 2003) of the Precambrian blocks and Paleozr ic ı nits of eastern central Asia, to draw a possible full oroclinal bend called here the Mongol-Hingan orocline (Fig. 1b). All these recent findings allowed the setting $u^{r} o^{\prime}$ a new analogue model which satisfied the geological, structural, geophysical and $\mathrm{p}_{a}{ }^{1}$ omagnetic constraints of the Mongolian orocline acquired during the last two decades (Lehmann et al., 2010; Guy et al., 2014, 2020; Edel et al., 2014) as well as the full wave-le $n_{5}$ th Mongol-Hingan oroclinal structure proposed by Yakubchuk (2004; 2017). Our analc gr e ulodel follows the existing studies of Pastor-Galán et al. (2012) and Boutelier et al., (.,v:9) who investigated the development and distribution of deformation structures of the $\mathrm{p}_{\mathrm{r}}$ ar crust, ductile deformation of the deep lithosphere and kinematic aspects related to the relative contribution of bending and buckling. The primary aim of our model is the analys of the three dimensional lower crustal fluxes and surface deformation governed by uninnal buckling of a vertical plate.

\section{Geodynamic back $\underset{z}{ }$ round}

The Mongolian orocline can be divided into five principal zones (Fig. 1) which can be described from the interior of the orocline to its external parts as follows: 1) Silurian to Carboniferous oceanic sediments of the Mongol Okhotsk ocean at the orocline core called here the Mongol-Okhotsk Zone, 2) the Mongolian Precambrian continental blocks, 3) the Late Proterozoic accretionary complexes intruded by Cambrian-Ordovician arc forming the Lake Zone, 4) the Ordovician accretionary wedge (Mongol-Altai Zone) and 5) the Devonian to Carboniferous volcano-sedimentary sequences imbricated with Ordovician to Devonian intra-oceanic ophiolites of the East Junggar in NW China and Trans-Altai Zone in south Mongolia (East Junggar-Trans Altai Zone). In the south the South Gobi Zone occurs, formed by Precambrian basement (Rojas-Agramonte et al., 2011) and its early Paleozoic cover which according to Yakubchuk (2004) represents the southern limb of the Hingan orocline.

In order to understand the pre-buckling architecture of this orocline, we need to briefly characterize the principal orogenic events responsible for the accretion of oceanic complexes 
onto Precambrian blocks forming an ca. $3000 \mathrm{~km}$ long linear belt (Fig. 2a). Accretion started during the Early Cambrian obduction of Late Proterozoic intra-oceanic arcs onto the Mongolian Precambrian 1 blocks (Štípská et al., 2010; Buriánek et al., 2017), followed by the formation of a Cambro-Ordovician Japan type arc above the subducting Panthalasian oceanic plate (Janoušek et al., 2018). Simultaneously an up to $2000 \mathrm{~km}$ long and several hundred kilometres wide volcano-sedimentary accretionary wedge of the Mongol-Altai Zone) developed outboard of the continental blocks (Barguzin - B, Tuva-Mongolia - TM, Dzavkhan-Baydrag - DB, Erguna - E) and the magmatic arc (Jiang et al., 2017) together with a wide supra-subduction oceanic domain formed by oceanic arcs and back arcs of the East Junggar-Trans Altai Zone. This supra-subduction system continued to form the accretionary wedge until the end of the Silurian (Soejono et al., 2018).

The Mongol-Okhotsk Ocean started to open in the Late Silurian in the back-arc position to the ongoing subduction of the main oceanic system (Wilhem et al., 2012; Fig. 2b). During the Early Devonian, the Mongol Altai Zone accretionary sec.ments and volcanics were metamorphosed and underwent partial melting thereby produ, $\|_{\varepsilon}$ granulitic-migmatitic lower crust accompanied by the massive intrusion of granitoids in th $\cdot \mathrm{r}_{\mathrm{l}}$ ddle and upper crust (Jiang et al., 2016). These anomalous thermal conditions resul eit er from the subduction of an active spreading oceanic ridge (e.g., Sun et al., 2009; C $\mathrm{i}$ eı al., 2010) or the elevation of the asthenosphere due to Pacific-type back-arc spreadin', a'ove a retreating oceanic plate (e.g., Jiang et al., 2016, 2019). During the Early Carbon. are $s$, the mobile and partially molten Mongol-Altai Zone lower crust was redistributed be neatı the East Junggar-Trans Altai Zone supra-subduction oceanic crust in the form of a $2 \mathrm{r} \mathrm{l} \mathrm{m}$ thick felsic to intermediate relaminant (Guy et al., 2015, 2020; Nguyen et al., 2018) Aı uils stage, the pre-buckling architecture of the Mongolian collage system consist $f$, $f$, the Mongol-Okhotsk oceanic subduction dipping beneath the 2) Mongolian Prec. abrian blocks forming dismembered continental ribbon attached to the 3) metamo nhosed wedge sediments of the Mongol-Altai Zone relaminating the 4) oceanic East Jungy.r-Trans Altai Zone crust in the south (schematic cross-section in Fig. 2b).

During the Early Permian the w. lolc Mongolian system suffered a major clockwise rotation (Cocks and Torsvik, 2007; Xia ) eı 1., 2015) at the end of which the Mongolian accretionary system formed a north-south rn nted belt located between the subducting Mongol-Okhotsk Ocean in the east and the rtre: ing "Paleo-Asian" Ocean in the west (e.g. Lehmann et al., 2010; Wilhem et al., 20² 2 ). Theoretically, the (Buryea, Jiamisu, Khanka (BJK) Precambrian

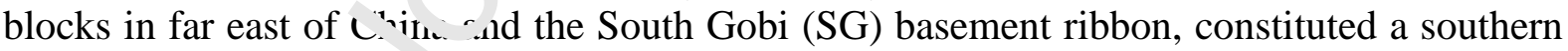
continuation of the future Mongolian-Hingan oroclinal system (Fig. 2d). The rapid northward movement of the Tarim-North China collage during the Permo-Triassic (e.g. Xiao et al., 2018; Edel et al., 2014) was responsible for the squeezing and buckling of this arcuate linear system about a sub-vertical axis between the northerly Siberian Craton and the southerly Tarim-North China collage (Fig. 2b-2c). During the closure of the Mongolian orocline, the Mongol-Okhotsk oceanic plate subducted both towards the south and north while the Mongol-Okhotsk Ocean closed in a scissor-like manner (Donskaya et al., 2012; Kelty et al., 2008). Subsequently, the Mongol-Hingan oroclinal system was affected by post-buckle flattening leading to the formation of deformation zones similar to axial planar crustal-scale cleavage (e.g. Lehmann et al., 2010; Guy et al., 2014a; Edel et al., 2014) (Fig. 2c-2d). This event was also accompanied by development of upright folds with horizontal axes in the Mongol-Altai Zone and the relaminated oceanic crust of the East Junggar-Trans Altai Zone (Guy et al., 2020). 


\section{Analogue model setup}

In order to understand the 3D deformation of the Mongol-Hingan oroclinal system, we designed a model setup that resembles the orogenic system described above prior to the oroclinal buckling (Fig. 2). The model setup corresponds to the Permo-Triassic orogenparallel shortening of the linear ribbon-like string of continental blocks and attached accretionary system between the Siberian and North China cratonic jaws (Edel et al., 2014). The evolution of the system was simulated by means of eight experiments allowing analysis of material transfers for individual time steps and a better understanding of the final internal architecture and structural pattern of the Mongolian orocline.

In our experiments we used Fontainebleau sand (to model the brittle behavior of the upper crust), silicone putties (to represent the ductile crust and upper mantle segments) and plasticine (the buckling of which represented the deformation of the continental ribbon) with rheological properties similar to those of Cagnard et al. (2iา6) and Brun (2002). The rheological parameters of individual model layers are descrit ed $\uparrow$ ' Table 1 and shown in Fig. 3. Our model does not contain the asthenosphere due to simnl preparation related to the need to introduce complex 1 oriz ontal and vertical layering in different domains of the model. The effect of this simpli. "cation is discussed later.

All experiments were conducted in the same analog e $m_{t}$ delling box. The modelled domain is divided in three subdomains shortened between a nobile piston and a stationary wall representing the Siberian and North China crate is 'The subdomain representing the MongolOkhotsk Ocean (MO) has a typical structure t: a 1 oceanic crust characterized by a thick segment of the upper mantle and relative $:-h_{1}$. crust represented by silicon putty overlain by Fontainebleau sand, respectively. The si ndr nain corresponding to a Precambrian continental ribbon and attached accretionary wedge of $:$ e Mongol Altai Zone (CRAW) is represented by vertical plasticine and silicon putty L'ocks, respectively (Fig 3). It is this curved vertical plasticine layer which represents $\_$: nn rolling layer of the buckle folding. The EJTA subdomain represents an oceanic in jer crust of the East Junggar-Trans Altai Zone underplated by a relaminant for'nea by the Mongol-Altai Zone metamorphosed rocks (Fig. $3 b$ ). It consists of silicone $\mathrm{pr}^{1} \mathrm{y}$ rupresenting the high viscosity upper mantle and the low viscosity middle and lower cr. st 'relaminant), overlain by Fontainebleau sand (brittle upper crust). Both the CRAW ana FJ A subdomains are underlain by silicon putty representing the upper mantle. The EJTf su domain is separated from the sandbox wall by silicone putty to minimize the boundary unition effects imposed by the immobile wall of the apparatus. We also reduced the friction etween the modelling box walls and the model materials by using petroleum jelly. Model geometry, the mechanical properties of the materials and the rheological profiles are shown in Fig. 3. In the model the fold cored by the MO subdomain is called the Mongolian fold, and the fold cored by the EJTA subdomain is called Hingan fold. This terminology is used to compare the structural pattern and deep crustal architecture of both Mongolian and Hingan oroclines.

\subsection{Model scaling}

The scaling between natural and laboratory conditions constrain the size of the modelled domain, the selection of the specific analogue materials used and the strain-rate (e.g. Brun, 2002; Cobbold and Jackson, 1992; Davy and Cobbold, 1988; Davy and Cobbold, 1991; Hubbert, 1937; Ramberg, 1981). Our analogue experiments reproduce the indentation and shortening of lithospheric domains associated with faulting and surface elevation in the upper crust, the coupling and flow of the lower crust, and the decoupling of the lithospheric mantle. Based on previous studies (e.g. Brun, 2002; Cagnard et al., 2006; Gapais et al., 2009), we set 
the model length to $30 \mathrm{~cm}$, the model width to $42 \mathrm{~cm}$ and the model height to $4 \mathrm{~cm}$ implying a space dimensions scaling factor $L^{*}=\frac{L_{M}}{L_{N}}=8 \cdot 10^{-7}$. We ran all experiments under normal gravity acceleration implying $G^{*}=1$. The scaling factor for densities $\left(P^{*}=\frac{\rho_{M}}{\rho_{N}}\right)$ is in the range of 0.481 and 0.497 . For viscosity $\left(M^{*}=\frac{\eta_{M}}{\eta_{N}}\right)$ the ratio varies from $1.2 \cdot 10^{-17}$ to $3.8 \cdot 10^{-17}$ (the scaling factors for all layers are displayed in Tab. 1). From these scaling factors it is possible to obtain the factors for stress, time, strain-rate and velocity using the following relationships:

$$
\begin{aligned}
\sigma^{*} & =P^{*} \cdot L^{*} \cdot G^{*} \\
T^{*} & =\frac{M^{*}}{\sigma^{*}}=\frac{t_{M}}{t_{N}} \\
\varepsilon^{*} & =\frac{\sigma^{*}}{M^{*}} \\
V^{*} & =\varepsilon^{*} \cdot L^{*}
\end{aligned}
$$

The accuracy of the dynamic scaling was tested by cr. laing the non-dimensional Ramberg numbers defined by the ratios between the forces acti ig on the model (Ramberg, 1981; Sokoutis et al., 2005). The appropriate scaling nur sbers for individual layers are shown in Tab. 2.

\subsection{Experimental procedure}

The experiments were repeated with an tical original setup (Fig. 3), for the same constant velocity of $2 \mathrm{~cm} / \mathrm{h}$ and finite short^ning or 25\%, 37\% and 50\% (Fig. 4). The laboratory temperature during all experiments wa $19-20{ }^{\circ} \mathrm{C}$. Reproducibility was verified by visual inspection of topography features $r_{1} a_{1}$ ig repeated experiments. Only a few negligible differences were noted, which w $₫$ a esult of small variations in the shape and thickness of the plasticine layer. The sectior $i_{i_{c}}$ of the deformed model domain was performed normal and parallel to the direction of shor ‘ning. The modelled domain was further frozen to eliminate undesirable deformation of silı on putty after the experiment. To obtain cross sections for different orientations and az s of model evolution, a series of identical experiments were carried out, each beir? $\mathrm{s}_{\mathrm{s}} \mathrm{pp} \mathrm{d}$ after different amounts of shortening.

Four cameras with differ $n$ nt elevations and view angles recorded the images of the model surface every 5 or 10 ininutes. One camera was situated directly above the experiment in order to observe the evolution of the modelled surface from the top view. This camera was used for 2D velocity field reconstructions (PIV - particle image velocimetry), while the other three cameras were used for the reconstruction of a 3D model topography using the MicMac software (e.g. Galland et al., 2016). For the detailed investigation of the upper crust deformation and topography evolution, the PIVlab software was used (Thielicke and Stamhuis, 2014) to determine the velocity field and the horizontal strain components (Krýza et al., 2019). The divergence of the velocity field was used to identify zones of localized thickening (negative divergence) or thinning (positive divergence) of the uppermost part of the model. These data were superimposed on the results obtained from the topography reconstruction to evaluate the mass transfer in a vertical direction.

\section{Results}


We present the first finite geometries after 50\% shortening for sections perpendicular (Fig. 5) and parallel (Fig. 6) to shortening directions to identify the main structural features of the model. The progressive evolution of structures and deduced material fluxes were obtained from analyses of sections representing different deformation increments (Fig. 7), model topography and deformation of the model surface (Fig. 8).

\subsection{Sections perpendicular to the shortening direction (i.e. parallel to the axial plane of the orocline)}

The sections perpendicular to the shortening direction expose two contrasting domains (Fig. 5): (1) on the piston side of the model the Mongolian Orocline fold hinge amplifies and indents towards the EJTA subdomain, sections 1 and 2), and (2) in the backstop part of the model, the Hingan fold hinge amplifies towards the MO subdomain (sections 4 and 5). The inflection part of the fold is examined in section 3. Sections 1 and 2 show a similar pattern characterized by generalized thickening of the ductile part of $t_{1}, \mathrm{MO}$ and EJTA subdomains. The main feature is the underthrusting of the EJTA subdom be neath the MO subdomain associated with the upright folding of the lower crust-mantle nte face. This underthrusting is accompanied by the exhumation of the EJTA mantle $b$ neith the propagating fold hinge. Section 3 shows that horizontal movements are lim te: 's the EJTA and MO mantle lithosphere, which are accompanied by minor extrving of the EJTA mantle beneath the CRAW subdomain. Sections 4 and 5 show a conside, rble thinning and extension of the EJTA subdomain lower and middle crust. This is accomp nie. by the thrusting of the CRAW and EJTA mantle lithosphere over the MO subdoma $n$.

\subsection{Sections parallel to the shortenin ${ }^{-}{ }_{1}{ }^{\circ}$ ction (i.e. perpendicular to the orocline axial plane)}

Section 1 of Fig. 6, shows deformation of ine MO subdomain and the tip of Hingan fold hinge. Section 4 shows the deformation of the EJTA subdomain and the tip of Mongolian fold hinge. Sections 2 and 3 presen $s$ r tures related to the deformation of the central parts of both folded domains. In order ${ }^{4} v$ har acterize deformation related exclusively to movement of the piston, we also present su tions 5 and 6 which are some distance from the folded domain. Here, we can observe - thickening of the mantle close to the piston (right) which decreases towards the back-stor (left). This is characteristic of a viscous deformation gradient typically developed in fr $\sim^{+} \omega_{-}^{*}$ the moving piston (e.g. England and Houseman, 1986, 1989; Ježek et al., 2002). The पJT † crust-mantle interface (section 5) is irregularly deformed and shows upright cuspate tc.' Is further away from the piston.

Section 4 intersects the up of the Mongolian fold hinge and exhibits an overall homogeneous shortening of the lithosphere. This is expressed by pop-down structures along the uppermiddle crust boundary and by the cuspate-lobate upright folding of both the crust-mantle and lower-middle crust interfaces. Section 3 is characterized by a contrasting response of the EJTA and MO subdomains. The EJTA subdomain fold hinge forms an antiformal domal structure formed by the middle crust. It is surrounded by marginal synforms and cored by the lower crust and the mantle associated with a cuspate-lobate folding of the crust-mantle interface. The MO crust-mantle boundary is characterized by the formation of pop-down structures while the interface of MO and CRAW-EJTA mantle forms a large scale synformal structure. The main feature of section 2 is the influx of the MO mantle into the EJTA subdomain below the amplified crustal antiformal domal structure. The core of the Hingan fold hinge area (section 2 on the left) also shows a décollement between overthrust crustal antiform and the EJTA mantle (see panels 4 and 5 in Fig. 5). Finally, section 1 reveals a homogeneous thickening of the MO subdomain accompanied by the deformation of the 
mantle-crust interface which exhibits pop-down structures similar to those described by Cagnard et al. (2006).

Two general features can be observed in these sections: 1) Indentation deformation gradients can be observed in regions outside the folded region in the mantle of both the EJTA and MO subdomains. 2) The folded region shows homogeneous deformation associated with the development of pop-down structures close to the axial plane of both the Mongol and Hingan fold hinges.

\subsection{Incremental evolution}

In order to better understand the significance of the general features described above we examine the evolution of the model along sections cross-cutting the folded region (section AB) and in the EJTA subdomain (section C-D), Fig. 7. The evolution of the system is examined in three repeated identical experiments with different finite shortening $25 \%, 37 \%$ and $45 \%$.

The folded region (sections A-B) reveals contrasting bel avi ur of the MO and EJTA subdomains and their interaction with the CRAW subr-main in the middle. The early shortening (25\%) is accommodated mainly by the thicke ing of the MO mantle and its flux into the EJTA subdomain, which remains weakly de ${ }^{c}$ ormed. In the second stage (37\% shortening) a massive flux of MO mantle from the $\mathrm{N}$. ongol fold hinge area towards the central part of the EJTA subdomain can be observea. This flow causes the formation of an inclined antiformal structure in the region of the axial plane of the Hingan fold. The subsequent stage of deformation (45\% shorteni $r_{\text {, ) }}$ hows an amplification of the antiformal dome structure cored by the EJTA lower rrils. that has been massively shortened by the MO mantle lithosphere indentation. Here, te rustal antiformal dome is decoupled from the EJTA mantle. The evolution described abc e is accompanied by the dynamic deformation of the upper crust which is progressiv ${ }^{1} v$ uplifted in the Hingan fold domain while in the Mongolian fold hinge area forms ' Vh. Form which evolves into a large-scale pop-down structure.

The EJTA subdomain (sections ' - D, Fig. 7) reveals a contrasting behaviour of the crust and the lithospheric mantle duriı $\iota_{c}$ the progressive shortening. The EJTA mantle exhibits a classical indentation thicken1. ${ }^{\text {r }}$ gradient in front of the piston (England and Houseman, 1986). As a consequence. a 1. ar.tle dome structure develops with a thinned crust in the apical part of the dome. In con rast, both the upper and lower oceanic crust thickens at the back-stop side of the model. Her , true upper crust thickening occurs through folding while the middle and lower crust thickenin r reflects homogeneous shortening associated with the development of cuspate-lobate structures at the crust-mantle and lower-middle crust interfaces.

\subsection{Evolution of model surface deformation}

A time-resolved particle image velocimetry (PIV) software tool was used to assess the deformation of the uppermost crust represented in the models by a sand layer, which was removed before model sectioning (Fig. 8). The shear strain-rate, velocity field patterns (Fig. 8a) and the corresponding divergence of the velocity field (Fig. 8b) are analyzed for four shortening stages $(3 \%, 25 \%, 37 \%$ and $45 \%)$. The analytical PIV post-processing approach is described in detail in Krýza et al. (2019).

In the early stages of the experiments (3\% shortening), the EJTA subdomain is homogeneously deformed, while the folded region shows velocity field related to active buckling (Fig. 8a). This buckling vanishes at $37 \%$ shortening when a velocity field typical of a post-buckle flattening (i.e. parallel velocity vectors) is established. Another feature is the surface deformation partitioning expressed by narrow zones of deformation develop at $25 \%$ 
and $37 \%$ of shortening in both the MO and EJTA subdomains (Fig. 8 - blue zones). The divergence of the velocity field becomes characterized by high frequency negative and positive anomalies, which developed preferentially along the axial planes in the hinge zones of both the Hingan and Mongolian folds (Fig. 8b). These anomalies correspond to the development of thrust related folds, which initiate the pop-up structures and the narrow synclines associated with the development of pop-down structures at deeper crustal levels (Krýza et al., 2019) described above (Fig. 7). With ongoing deformation (45\% shortening), the whole domain is governed by homogeneous deformation marking a post-buckle flattening mode of deformation (Fig. 8a). The final topography reconstruction after $50 \%$ shortening (Fig. 8c) shows well developed positive topography anomalies along the folded region and positive narrow linear ranges, which correspond to the thrust related folds in Fig. 7. The narrow and low topography anomalies correspond to the above mentioned negative values of divergence associated with the narrow synclines, while large topography anomalies correspond to positive values of divergence associated with $t_{1}$ development of the pop-up structures. Wide plateaus of neutral to high topography are rvveisped in both the MO and EJTA subdomains close to the piston side. Velocity profilt: fo various shortening values (Fig. 8d) show a linear decrease of velocity distribution t. pic. 1 of homogeneous deformation for small amounts of shortening. Starting from 25\% (f $\cdots$ shortening the velocities are characterized by variations typical of heterogeneous $\mathcal{H}_{c}$. ormation. The highest strains are partitioned along the axial plane of the Hingan fold $k$ nge

\section{Discussion}

\subsection{Model limitations related to bov . 1 i. ry conditions}

A limitation of our modelling is the absen ${ }^{\circ}$ of a dense viscous fluid used as a proxy to the asthenospheric mantle in the model of Cagnard et al., (2006). Actually, due to the rather complex geometry of the modelled '..hosphere, the technical realization and exploitation of an asthenospheric-scale model would a ve been impossible. The absence of dense fluid at the bottom of the model is the likel $\mathrm{re}$. son for the development of the deformation gradient in front of the piston in the EJTA abdomain (Figs. 6, 7 and 8). This deformation feature, known as an indentation prof: ${ }^{1}$ e, i typical of numerical models based on a viscous, thin sheet approximation with the rig. ${ }^{-1}$ flıor (England and Houseman, 1986; Ježek et al., 2002). This imposes a vertical extru, 10. of material exponentially decaying away from the front of the indenter (Lexa et al., $\left(\iota^{2}\right)$. It should be noted that the indentation profile is only weakly developed in the folded 1 :gion (Fig. 6) and disappears at high finite shortening (Figs. 7 and 8). An important feature of models with a fluid asthenosphere is the absence of an indentation profile and the development of homogeneous thickening of mantle lithosphere across-strike of the modelled domain (Fig. 3 in Cagnard et al., 2006). Therefore, our model resembles the homogeneously distributed deformation within the deep lithosphere either in the folded region (Sections A-B in Fig. 7) or for a high degree of the shortening (Fig. 8). The indentation profile developed in the EJTA subdomain is therefore considered as an artefact of the model setup and is not used in further geological interpretations. Therefore, we suggest that the mutual interactions between the MO and the EJTA subdomains during oroclinal buckling would be similar to that which is found to occur when a dense viscous fluid is present at the base of the model.

Another limitation of the model is the presence of high deformation gradients adjacent to the fixed lateral walls of the model box (Fig. 8). Complex structures developed in these regions Fig. 5), which are excluded from interpretations. Only the internal part of the modelled domain is considered. 
In addition, our model cannot produce heterogeneous mantle thickening in the hinge zone of the orocline as modelled by Pastor-Galán (2012). The reason is that the controlling layer for buckling in their model is oriented horizontally and the bulk deformation is restricted to the folded domain. In contrast, in our model, the controlling layer for buckling is a vertical thin beam surrounded by viscous silicone putty and therefore most of the displacement occurs within the horizontal plane.

\subsection{Mantle and crustal fluxes related to oroclinal buckling}

The analyses of finite strain patterns along the axial planes of the oroclines and on the sections parallel and orthogonal to the shortening direction together with the study of the incremental evolutions of these sections and surfaces, allow the relationships between deep lithospheric fluxes and surface deformation related to the oroclinal buckling to be determined. A major zone of mechanical decoupling is develop ${ }^{\prime}$ along the interface between the brittle upper crust (sand) and the viscous middle-low er rust (silicone putty). It is manifested by contrasting deformation patterns within the vis 'n's and brittle parts which are apparent up to a shortening of $\sim 40 \%$. While the viscous , art of the model exhibits a typical indentation profile in front of the piston, the brittle laye is detached and most of the deformation is localized along the axial plane of Hin a a. tuld. During subsequent shortening, this independent behaviour gradually vanishes and atr parts of the model exhibit a more coupled deformation.

However, the deformation pattern is differe $n$. I elow the folded accretionary domain (CRAW). Here, the lateral fluxes parallel to ti. fold axial planes dominate the deformation of both types of mantle lithosphere, whict ar dragged by the migrating orocline hinges in a vortex manner (Fig. 9). In this way, the "vo contrasting mantle lithospheres are laterally juxtaposed in the region where the MO mantle flows towards the hinge domain of the Mongolian fold (sections 1 and $2 ;.$ Fig. 5), and the EJTA lithosphere flows towards the Hingan fold (section 4 in Fig. 5). $W$ : r ote that both oroclinal bends reveal more important displacement of the fold hinge in $t^{*}$ crustal level compared to the crust-mantle boundary. This is expressed by the opp' site general inclination of subdomain boundaries associated with thrusting of the MO ov $r$ ise EJTA lithosphere in sections 1 and 2 and the opposite thrusting in section 4 (Fig. - ? The inclination angle of the fold axes and associated thrusts of the lithospheric segmen's 1 soverned by differences in vortex velocity between the mantle and upper crust as a d $u$ from the serial sections and the PIV analysis of the surface deformation (Figs. 5, 6, $; \&$ 8). It can be shown that the vortex velocity at the surface is high compared to the slower tlow of the viscous mantle at depth (Fig. 9). This velocity difference implies a progressive rotation over time of the orocline fold axes from vertical to less inclined orientations and the above-described thrusting of mantle lithosphere.

These redistributions of mantle and crustal materials are associated with the formation of an antiformal fold with a horizontal axis in the region of the Hingan fold and a horizontal synform in the Mongolian fold domain. These processes are also reflected in the surface where the pop-down structures dominate the Mongolian fold hinge, while the Hingan fold hinge shows the presence of a central antiform surrounded by narrow, marginal synclines (Fig. 7).

The consequence of oroclinal buckling is the development of a region dominated by lowermiddle crustal material in the Hingan fold hinge compared to the mantle dominated region in the Mongolian fold hinge zones. Mechanically, the Hingan fold hinge is represented by a multi-layer system formed by the stiff EJTA mantle at the bottom, overlain by extremely weak lower and middle crustal layers and the strong upper crust higher in the column. In 
contrast, the Mongolian fold hinge is formed exclusively by the MO oceanic mantle and a thin upper crust. Therefore, the integrated strength of the EJTA multilayer system (England and Houseman, 1986; England and Houseman, 1989; Thompson et al., 2001) is significantly lower compared to the adjacent MO lithosphere. This difference implies that under horizontal compression the EJTA subdomain collapses and shortens preferentially. The deformation is controlled by the presence of a strong substratum overlain by a weak layer which is an ideal condition for detachment of a weak lower crust from the rigid upper mantle and the buckling of the stronger, middle-upper crustal layer. The formation of the detachment antiform in the Hingan fold hinge area is accompanied by the flux of MO mantle and the progressive development of material deficit in the EJTA subdomain close to piston leading to the formation of a large-scale synform filled with oceanic crust decorated by pop-down structures at the surface.

\subsection{Is the deformation driven by top or bottom fluxes}

Tikoff and Teyssier (2002) discussed the deformation of th- li.hosphere and argue that it occurs either by movements of the mantle layer (i.e. bott $\mathrm{m}$ c iven tectonics) or by the rigid crust (i.e. top driven tectonics). In order to determine vich of these two models is the more likely, it is necessary to determine which layer is rachaıically dominant and controls the deformation of the whole system. We have shown int he primary response of the mantle lithosphere with a low mechanical anisotropy is t'ie du velopment of a typical indentation profile (Figs. 6 and 7 - lateral view; Fig. 8a). B itt. c rustal sections and surface analysis show that during the early stages of the experim 'nts une mantle governs the bulk lithospheric deformation. However, this behavior ch 'ng s rapidly after ca. 5-10\% shortening i.e. during the maximum amplification of the oroc. e within the crust. The significant crustal flow related to the fold amplification iffects me mantle flow which is manifested by the development of vortex flow in the ma.tle (Fig. 9). During this stage, the folding of the CRAW subdomain governs the $b$ sh material fluxes in its vicinity leading to the accumulation of oceanic mantle in terial in the Mongolian fold and of the EJTA crustal material in the Hingan fold. After a. 30\% shortening the active folding ceases and the postbuckle flattening, i.e. homoremous flattening, takes over. This point is reached when the layering has rotated intc an almost stable position with increased resistance to the deformation along the $\mathrm{s}^{2}{ }^{-}{ }^{+} \mathrm{e}_{1.1}$ ng direction. The deformation becomes partitioned between the two orocline axi-1 1 m ins because of the different integrated strengths of these two domains. During this tage, the lithospheric deformation progressively passes to a mechanically coupled unavior. The mechanical evolution of the system is transient and characterized by three stages starting with bottom driven flux of the mantle, followed by top driven stage during amplification of orocline and terminating with fully coupled deformation.

\subsection{Large scale geological implications for intra-oceanic oroclinal systems}

The analyses of the finite strain patterns and lower crustal and mantle fluxes described above allow the first order features of the model to be defined: 1) redistribution of EJTA mantle beneath the Mongolian fold hinge, 2) important crustal thickening of the Mongolian fold hinge related to underthrusting of EJTA crust beneath the CRAW subdomain and 3) intensive deformation of the EJTA crust and formation of pop-down structures along the axial plane of the Hingan fold. An attempt is made to correlate these features with the main geophysical and geological observations of the Mongolian part of the CAOB. 
The CAOB is traditionally interpreted as a result of long-lived accretion of highly contrasting lithospheric terranes such as continental blocks, magmatic arcs, oceanic lithosphere and accretionary prisms (Badarch et al., 2002; Windley et al., 2007). In theory, these terranes should be composed of crust and lithospheric mantle that differ in thickness and composition. However, even if the geological expression of suspect terranes seems to be valid, the geophysical data show to a certain degree homogeneous lower crust beneath the EJTA and the CRAW (Guy et al., 2014; 2015; 2017). In addition, the massive alkaline Permo-Triassic magmatism affecting this vast region reflects the same mantle source beneath both the EJTA and the MO domains (e.g. Kovalenko et al., 2004; Yarmolyuk et al., 2007). In our analogue model, these observations are supported by the redistribution of the EJTA mantle beneath the central part of the folded domain, in particular the hinge of the Mongolian orocline (section 3 in Fig. 6).

The geophysically derived MOHO depth beneath the Mnngolian CAOB reveals that maximum crustal thickness occurs beneath the hinge of the Mo.. solian orocline and the Altai mountains (Guy et al., 2017). The periphery of this domair is also marked by presence of UHT Permian granulites suggesting major thermal pertu hat on in the mantle depths (Burenjargal et al., 2014; Li et al., 2004; Broussolle et a! , 2( 18a) related to the progressive growth of the orocline (Jiang et al., 2019; Guy et al., ' 0 ' $\angle$ u). These observations indicate a major mobility of the hot felsic crust during Permia $\therefore$ in $n$ s and its redistribution associated with the growth of the hinge of Mongolian orocline. In sur model, the crustal thickening in this domain could result from overthrusting of the M.ong lian fold hinge over the EJTA crust during orocline amplification (sections 1 and $2 \mathrm{ir}$. Fig. 5). Indeed, the underthrusting of the East Junggar-Trans Altai Zone lower crust $h \geq n e_{a u l}$ the hinge of Mongolian orocline in the Chinese Altai was shown by both structr'al 'Jiaı.g et al., 2019) and geophysical data (Guy et al., 2020). The interpretation of this coms' $x$ boundary is portrayed in Fig. 10 which shows a large gravity high beneath the East Junggar basement (western part of the East Junggar-Trans Altai Zone) continuing far beneath the Thinese Altai (western continuation of the Mongol Altai Zone). The gravity modeling is il cerpreted in terms of the emplacement of the dense East Junggar-Trans Altai Zone rı ${ }^{+}$veneath the low density Mongol Altai Zone crust, and the thickening and exhumatic $1 f$ both Permian granulites and the Devonian migmatitemagmatite dome further north. The analogue model presented here thus explains the far travelling underthrusting of the Jast Junggar-Trans Altai Zone crust beneath the Chinese part of the Mongol Altai Zor - Jeciuced from gravity modelling and the thrusting of the Mongol Altai Zone sequenc c ver the imbricated East Junggar-Trans Altai Zone oceanic crust (Briggs et al., 2007 ( $\mathrm{F}_{\mathrm{s}}$ 10). The Permian thermal anomalies and related melting of the lower crust can be expinined as a consequence of the elevation of EJTA mantle beneath the folded domain as shown in our model (Fig. 5).

Several structural and geophysical studies from south Mongolia report the existence of steep E-W trending deformation zones associated with localized elongated gravity highs in the East Junggar-Trans Altai and Mongol Altai zones (Fig. 11). Linear gravity highs have been interpreted as a result of the shortening of the upper crust and its downward penetration into the homogeneous lower crust along vertical zones as deep as $20 \mathrm{~km}$ (Guy et al., 2014b). These gravity highs correspond to Permian-Triassic upright synforms with horizontal axes which folded Devonian ophiolites composed of dense mafic gabbroic and basaltic crust and peridotites (Guy et al., 2014a). These deformation synforms developed simultaneously with the oroclinal buckling in the East Junggar-Trans Altai and Mongol Altai zones (Guy et al., 2014a; Lehmann et al., 2010). This period is also connected with the formation of E-W trending Permian volcanic rift zones (Kovalenko et al., 2004) marked by important magnetic lineaments in the East Junggar-Trans Altai Zone in south Mongolia. We suggest that pop- 
down structures affecting the EJTA subdomain simulated in this study are an excellent explanation for linear gravity and magnetic anomalies affecting the East Junggar-Trans Altai Zone in south Mongolia (Guy et al., 2014b). Both the upright synforms, vertical deformation and linear rift zones described is south Mongolia and NW China can be compared to linear pop-down and pop-up structures visualized in the surface model analysis (Fig. 8) and sections perpendicular to the axial plane of large oroclines (Fig. 6).

The global correspondence between the results of the analogue model and existing structural and geophysical data from southern Mongolia and NW China is shown in Fig. 12. The 3D geology model in Fig. 12a shows the final geometry the folded system while the sections perpendicular to the axial planes of the oroclines show possible geometries along their hinges and limbs (Fig. 12b). Both structures and thermal anomalies developed at the East JunggarTrans Altai Zone and Mongol Altai Zone boundary in NW Chinaare compatible with the progressive emplacement of MO mantle beneath the hinge of the Mongolian orocline (Fig. 12b) and lower crustal fluxes parallel to the axial plane of bo the Mongolian and Hingan oroclines. The main consequence is the redistribution of hom oy neous EJTA mantle beneath the hinge of the Mongolian orocline and adjacent rear part of the Aingan orocline. The model shows both the development of pop down structures is the core of the Hingan orocline compatible with the development of deep narrow synf rrmı and linear gravity highs in the East Junggar-Trans Altai Zone in south Mongolia $\left(i_{i} .11\right)$ and underthrusting of the East Junggar-Trans Altai Zone upper-middle crust beneas' tr e exhumed hinge of the Mongolian orocline (Fig. 10).

\section{Conclusions}

This study represents a new approach o the simulation of the mechanical processes associated with the building of lary oroclinal systems that are associated with a lateral compression. It investigates the mas tra. sfer at the model surface, which is responsible for the deformation of the upper crust an 1 or the development of topography. Furthermore, the ductile flows inside the model au nains and the mechanical coupling in a lithospheric multilayer are studied from he model sections. The main modelling features can be summarized as follows:

- The lateral shortenin $\mathrm{O}^{t}$ the pre-folded accretionary belt leads to the development of two regional-sca'e ty, es of folds: the steeply plunging oroclinal folds and the smaller scale upright $\mathrm{L}^{1} \mathrm{~d} d \mathrm{~s}$ with sub-horizontal fold axes which are formed in the MO and EJTA subdomains

- Generally, all curvilinear fold-thrust systems developed in the upper crust express the geometry of the axial planes of upright folds developed in deeper lithospheric layers.

- The overthrusting of the oceanic MO lithosphere and the continental CRAW crust over the EJTA crust in the Mongolian orocline hinge is associated with the material vortex flow around the inflection of the orocline. This pattern decays towards deeper lithospheric layers, where the lateral flow of material is negligible.

- The analogue model explains the far travelling underthrusting of the East JunggarTrans Altai Zone crust beneath the Mongol Altai Zone sequences in NW China deduced from gravity modelling and the geometry of East Junggar-Trans Altai Zone oceanic crust.

- The redistribution of EJTA mantle material related to the oroclinal buckling may explain the presence of homogeneous mantle beneath both the Mongolian and Hingan oroclines. In addition, simulated pop-down structures in the analogue model are 
consistent with the presence of linear zones of gravity highs associated with vertical zones coinciding with synforms cored by dense ophiolites in the the East JunggarTrans Altai Zone in south Mongolia.

\section{Acknowledgments}

This paper was supported by the Czech Science Foundation GAČR EXPRO grant GX19$27682 \mathrm{X}$ to $\mathrm{KS}$. The Center for Geosphere Dynamics (UNCE/SCI/006) is acknowledged for the support of OL and OK. National Natural Science Foundation of China (41888101) for WX. We thank to J. J. Kermarrec for his help in the modelling laboratory at Géosciences Rennes, University of Rennes 1, France.

Primary data for this paper are available on https://doi.org/10.7 910/DVN/QNFHDO, Harvard Dataverse

\section{Conflict of Interests Statement}

We declare that the submitted work was carried writh 'it the presence of any personal, professional or financial relationships that could $\mathrm{F}$.ten ally be construed as a conflict of interest.

\section{References}

Badarch, G., Cunningham, W. D., \& W viley, B. F. (2002). A new terrane subdivision for Mongolia: implications for the Phanerozoic urustal growth of Central Asia. Journal of Asian Earth Sciences, 21(1), 87-110.

Boutelier, D., Gagnon, L., Johnston, ',.. \& Cruden, A. (2019). Buckling of orogens: insights from analogue modelling. Journc l oj Structural Geology, 125, 213-217.

Briggs, S. M., Yin, A., Manni o, C. E., Chen, Z. L., Wang, X. F., \& Grove, M. (2007). Late Paleozoic tectonic history of are Ertix Fault in the Chinese Altai and its implications for the development of the Central ' si in Orogenic System. Geological Society of America Bulletin, 119(7-8), 944-960.

Broussolle, A., Aguilar, `., Sun, M., Schulmann, K., Štípská, P., Jiang, Y., Yu, Y., Xiao, W. \& Míková, J. (2018a). Sr ıycyclic Palaeozoic evolution of accretionary orogenic wedge in the southern Chinese Altai: Evidence from structural relationships and $\mathrm{U}-\mathrm{Pb}$ geochronology. Lithos, 314, 400-424.

Brun J.-P. (2002) Deformation of the continental lithosphere: Insights from brittle-ductile models. Geological Society, London, Special Publications, 200, 355-370.

Burenjargal, U., Okamoto, A., Kuwatani, T., Sakata, S., Hirata, T., \& Tsuchiya, N. (2014). Thermal evolution of the T seel terrane, SW Mongolia and its relation to granitoid intrusions in the Central Asian Orogenic Belt. Journal of Metamorphic Geology, 32(7), 765-790.

Buriánek, D., Schulmann, K., Hrdličková, K., Hanžl, P., Janoušek, V., Gerdes, A., \& Lexa, O. (2017). Geochemical and geochronological constraints on distinct Early-Neoproterozoic and Cambrian accretionary events along southern margin of the Baydrag Continent in western Mongolia. Gondwana Research, 47, 200-227.

Cagnard F., Brun J.-P., Gapais D. (2006) Modes of thickening of analogue weak lithospheres. Tectonophysics, 421, 145-160. 
Cai, K., Sun, M., Yuan, C., Zhao, G., Xiao, W., Long, X., \& Wu, F. (2010). Geochronological and geochemical study of mafic dykes from the northwest Chinese Altai: Implications for petrogenesis and tectonic evolution. Gondwana Research, 18(4), 638-652.

Carey, S. W. (1955). The orocline concept in geotectonics-Part I. In Papers and proceedings of the Royal Society of Tasmania (Vol. 89, pp. 255-288).

Cobbold, P.R. and Jackson M.P.A. (1992) Gum rosin (colophony): A suitable material for thermomechanical modeling of the lithosphere. Tectonophysics, 210, 255-271.

Cocks, L. R. M., \& Torsvik, T. H. (2007). Siberia, the wandering northern terrane, and its changing geography through the Palaeozoic. Earth-Science Reviews, 82(1-2), 29-74.

Davy P. and Cobbold P. R. (1988) Indentation tectonics in nature and experiment. 1. Experiments scaled for gravity. Bulletin of the Geological Institutions of Uppsala, 14, 129141.

Davy, P. and Cobbold, P. R. (1991) Experiments on shortenin of a 4-layer model of the continental lithosphere. Tectonophysics, 188, 1-25.

Donskaya, T. V., Gladkochub, D. P., Mazukabzov, A. M., uc W aele, B., \& Presnyakov, S. L. (2012). The Late Triassic Kataev volcanoplutonic ass xi atir, n in western Transbaikalia, a fragment of the active continental margin of the Mong '-Okhotsk Ocean. Russian Geology and Geophysics, 53(1), 22-36.

Edel J.-B., Schulmann K., Hanžl P., Lexa O. (2v:4) Palaeomagnetic and structural constraints on $90^{\circ}$ anticlockwise rotation in $\mathrm{S} N$ Mongolia during the Permo-Triassic: implications for Altaid oroclinal bending. Joui na _s Asian Earth Sciences, 94, 157-171.

England, P., \& Houseman, G. (1986). Fi ite straın calculations of continental deformation: 2. Comparison with the India-Asia collisic. zone. Journal of Geophysical Research: Solid Earth, 91(B3), 3664-3676.

England, P., \& Houseman, G. (1\%0?). Extension during continental convergence, with application to the Tibetan Platear Jc urnal of Geophysical Research: Solid Earth, 94(B12), 17561-17579.

Gapais, D., Cagnard, F., Gueyı ^n, F., Barbey, P., \& Ballevre, M. (2009). Mountain building and exhumation processes thr 'igh time: inferences from nature and models. Terra Nova, 21(3), 188-194.

Galland, O., Bertelsu ` ' '., Guldstrand, F., Girod, L., Johannessen, R. F., Bjugger, F., Burchardt, S. \& Mair, 1. (2016). Application of open-source photogrammetric software MicMac for monitoring surface deformation in laboratory models. Journal of Geophysical Research: Solid Earth, 121(4), 2852-2872.

Gutiérrez-Alonso, G., Johnston, S. T., Weil, A. B., Pastor-Galán, D., \& Fernández-Suárez, J. (2012). Buckling an orogen: The Cantabrian Orocline. GSA Today, 22(7), 4-9.

Guy A., Schulmann K., Clauer N., Hasalová P., Seltmann R., Armstrong R., Lexa O., Benedicto A. (2014a) Late Paleozoic-Mesozoic tectonic evolution of the Trans-Altai and South Gobi Zones in southern Mongolia based on structural and geochronological data. Gondwana Research, 25, 309-337.

Guy, A., Schulmann, K., Munschy, M., Miehe, J. M., Edel, J. B., Lexa, O., \& Fairhead, D. (2014b). Geophysical constraints for terrane boundaries in southern Mongolia. Journal of Geophysical Research: Solid Earth, 119(10), 7966-7991.

Guy, A., Schulmann, K., Janoušek, V., Štípská, P., Armstrong, R., Belousova, E., Dolgopolova, A., Seltmann, R., Lexa, O., Jiang, J. \& Hanžl, P. (2015). Geophysical and 
geochemical nature of relaminated arc-derived lower crust underneath oceanic domain in southern Mongolia. Tectonics, 34(5), 1030-1053.

Guy, A., Holzrichter, N., \& Ebbing, J. (2017). Moho depth model for the Central Asian Orogenic Belt from satellite gravity gradients. Journal of Geophysical Research: Solid Earth, 122(9), 7388-7407.

Guy, A., Schulmann, K., Soejono, I., \& Xiao, W. (2020). Revision of the Chinese Altai-East Junggar Terrane Accretion Model Based on Geophysical and Geological Constraints. Tectonics, 39(4), e2019TC006026.

Guy A., Schulmann, K., Soejono, I., Holzrichter, N., Lexa, O. and Munschy, M. (2020) Structures and geodynamics of the Mongolian tract of the Central Asian Orogenic Belt constrained by potential field analyses. Gondwana Research, In review.

Han, Y., \& Zhao, G. (2018). Final amalgamation of the Tjanshan and Junggar orogenic collage in the southwestern Central Asian Orogenic Belt: cor traints on the closure of the Paleo-Asian Ocean. Earth-Science Reviews, 186, 129-152.

Hubbert M.K. (1937) Theory of scale models as applied to the zaddy of geological structures. Geological Society of America Bulletin, 48, 1459-1520.

Janoušek, V., Jiang, Y., Buriánek, D., Schulmann, K., Yanžl, P., Soejono, I., Kröner, A., Altanbaatar, B., Erban, V., Lexa, O., Ganchuluu ${ }^{*}$ T. \& Košler, T. (2018). CambrianOrdovician magmatism of the Ikh-Mongol Arc Sys.m exemplified by the Khantaishir Magmatic Complex (Lake Zone, south-centra' ivongolia). Gondwana Research, 54, 122149.

Ježek, J., Schulmann, K., \& Thompsor, t . L (2002). Strain partitioning in front of an obliquely convergent indenter. EGU Step ‘ Mueller Special Publ Ser, 1, 93-104.

Jiang, Y.D., Schulmann, K., Sun, M., Štípska, P., Guy, A., Janoušek, V., Lexa, O. and Yuan, C. (2016) Anatexis of accretionar; w-tge, Pacific-type magmatism, and formation of vertically stratified continental crus ¿ n ne Altai Orogenic Belt. Tectonics, 35(12), pp.30953118 .

Jiang, Y.D., Schulmann, K., 'röıır, A., Sun, M., Lexa, O., Janoušek, V., Buriánek, D., Yuan, C. and Hanžl, P. $(20: 7)$ Neoproterozoic-Early Paleozoic Peri-Pacific Accretionary Evolution of the Mongoliaı Cr llage System: Insights from Geochemical and U-Pb Zircon Data from the Ordovici in i edimentary Wedge in the Mongolian Altai. Tectonics, 36(11), pp.2305-2331.

Jiang, Y. D., Schulman^, K., Sun, M., Weinberg, R. F., Štípská, P., Li, P.F., Zhang, J., Chopin, F., Wang, S., Xia, X. P., Xiao, W. J. (2019) Structural and Geochronological Constraints on Devonian Suprasubduction Tectonic Switching and Permian Collisional Dynamics in the Chinese Altai, Central Asia. Tectonics, 38(1), 253-280.

Johnston, S. T., Weil, A. B., \& Gutiérrez-Alonso, G. (2013). Oroclines: Thick and thin. Bulletin, 125(5-6), 643-663.

Kelty, T. K., Yin, A., Dash, B., Gehrels, G. E., \& Ribeiro, A. E. (2008). Detrital-zircon geochronology of Paleozoic sedimentary rocks in the Hangay-Hentey basin, north-central Mongolia: implications for the tectonic evolution of the Mongol-Okhotsk Ocean in central Asia. Tectonophysics, 451(1-4), 290-311.

Kovalenko, V. I., Yarmolyuk, V. V., Kovach, V. P., Kotov, A. B., Kozakov, I. K., Salnikova, E. B., \& Larin, A. M. (2004). Isotope provinces, mechanisms of generation and sources of the continental crust in the Central Asian mobile belt: geological and isotopic evidence. Journal of Asian Earth Sciences, 23(5), 605-627. 
Krýza, O., Závada, P., \& Lexa, O. (2019). Advanced strain and mass transfer analysis in crustal-scale oroclinal buckling and detachment folding analogue models. Tectonophysics, 764, 88-109.

Lehmann J., Schulmann K., Lexa O., Corsini M., Kröner A., Štípská P., Tomurhuu D. and Otgonbator D. (2010) Structural Constraints of the Evolution of the Central Asian Orogenic Belt in sw Mongolia. American Journal of Science, 310, 575- 628.

Lexa, O., Schulmann, K., \& Ježek, J. (2003). Cretaceous collision and indentation in the West Carpathians: View based on structural analysis and numerical modeling. Tectonics, 22(6).

Li, Z. L., H. L. Chen, S. F. Yang, C. W. Dong, W. J. Xiao, J. L. Li, Y. Ye, and J. Wang (2004), Discovery and genetic mechanism of basic granulite in the Altay orogenic belt, Xinjiang, NW China, Acta Geologica Sinica-English Edition, 78, 177-185.

Menant, A., Sternai, P., Jolivet, L., Guillou-Frottier, L., \& Gt :a, T. (2016). 3D numerical modeling of mantle flow, crustal dynamics and magma genes s ssuciated with slab roll-back and tearing: The eastern Mediterranean case. Earth and Plar. „to y Science Letters, 442, 93107.

Nguyen, H., Hanžl, P., Janoušek, V., Schulmann, K Ulrich, M., Jiang, Y., Lexa, O., Altanbaatar, B. and Deiller, P. (2018) Geochemist y a רa geochronology of Mississippian volcanic rocks from SW Mongolia: Implications for a rane subdivision and magmatic arc activity in the Trans-Altai Zone. Journal of Asiar Furth Sciences, 164, pp.322-343.

Parfenov, L. M., Khanchuk, A. I., Badarch, G, ' 111 sr, R. J., Naumova, V. V., Nokleberg, W. J., Ogasawara, M., Prokopiev, A. V. ^ 1 'n, H. (2003). Preliminary northeast Asia geodynamics map (No. 2003-205). US C ool , gical Survey.

Pastor-Galán D., Gutiérrez-Alonso F., Zulauí G. and Zanella F. (2012) Analogue modeling of lithospheric-scale orocline buckling: Innstraints on the evolution of the Iberian-Armorican Arc. Geological Society of America B1 li in, 124, 1293-1309.

Ramberg, H. (1981) Gravity, De' or 'atıon and the Earth Crust. Academic Press, London and New York.

Rojas-Agramonte, Y., Kröneı, A., Demoux, A., Xia, X., Wang, W., Donskaya, T., Liu, D. \& Sun, M. (2011). Detrital ani xe nocrystic zircon ages from Neoproterozoic to Palaeozoic arc terranes of Mongolia: s' gnı "cance for the origin of crustal fragments in the Central Asian Orogenic Belt. Gondwu "a i.esearch, 19(3), 751-763.

Rosenbaum, G., \& Lis ${ }^{\circ}$, G. S. (2004). Formation of arcuate orogenic belts in the western Mediterranean region. Geological Society of America Special Papers, 383, 41-56.

Rosenbaum, G. (2014). Geodynamics of oroclinal bending: Insights from the Mediterranean. Journal of Geodynamics, 82, 5-15.

Şengör, A. M. C., Natal'In, B. A., \& Burtman, V. S. (1993). Evolution of the Altaid tectonic collage and Palaeozoic crustal growth in Eurasia. Nature, 364(6435), 299.

Şengör, A. M. C., \& Natal'In, B. A. (1996). Turkic-type orogeny and its role in the making of the continental crust. Annual Review of Earth and Planetary Sciences, 24(1), 263-337.

Shaw, J., Johnston, S. T., \& Gutiérrez-Alonso, G. (2015). Orocline formation at the core of Pangea: A structural study of the Cantabrian orocline, NW Iberian Massif. Lithosphere, 7(6), 653-661.

Shaw, J., \& Johnston, S. T. (2016a). Terrane wrecks (coupled oroclines) and paleomagnetic inclination anomalies. Earth-Science Reviews, 154, 191-209. 
Shaw, J., \& Johnston, S. T. (2016b). Oroclinal buckling of the Armorican ribbon continent: An alternative tectonic model for Pangean amalgamation and Variscan orogenesis. Lithosphere, 8(6), 769-777.

Soejono, I., Čáp, P., Míková, J., Janoušek, V., Buriánek, D., \& Schulmann, K. (2018). Early Palaeozoic sedimentary record and provenance of flysch sequences in the Hovd Zone (western Mongolia): Implications for the geodynamic evolution of the Altai accretionary wedge system. Gondwana Research, 64, 163-183.

Sokoutis, D., Burg, J. P., Bonini, M., Corti, G., \& Cloetingh, S. (2005). Lithospheric-scale structures from the perspective of analogue continental collision. Tectonophysics, 406(1-2), $1-15$.

Sun, M., Long, X., Cai, K., Jiang, Y., Wang, B., Yuan, C., Zhao, G., Xiao, W. \& Wu, F. (2009). Early Paleozoic ridge subduction in the Chinese Altai: insight from the abrupt change in zircon Hf isotopic compositions. Science in China Series L: Earth Sciences, 52(9), 13451358.

Štípská, P., Schulmann, K., Lehmann, J., Corsini, M., Lexi, O, \& Tomurhuu, D. (2010). Early Cambrian eclogites in SW Mongolia: evidence tl at ive Palaeo-Asian Ocean suture extends further east than expected. Journal of metamorp. ic こeology, 28(9), 915-933.

Thielicke, W., \& Stamhuis, E. (2014). PIVlab-towar is u er-friendly, affordable and accurate digital particle image velocimetry in MATLAB. Jourm-1 of Open Research Software, 2(1).

Tikoff, B., Teyssier, C., \& Waters, C. (2002). Civ ch tectonics and the partial attachment of lithospheric layers. EGU Stephan Mueller Spe i. P iblication Series, 1, $57-73$.

Thompson, A. B., Schulmann, K., Je ek J., \& Tolar, V. (2001). Thermally softened continental extensional zones (arcs $\mathrm{c}^{\mathrm{n}} \mathrm{.}$ rifts) as precursors to thickened orogenic belts. Tectonophysics, 332(1-2), 115-141.

Weil, A. B., Gutiérrez-Alonso, G., 'Thı ton, S. T., \& Pastor-Galán, D. (2013). Kinematic constraints on buckling a lithospher. sc sle orocline along the northern margin of Gondwana: A geologic synthesis. Tectonoph su. ग82, 25-49.

Wilhem, C., Windley, B. F., \& sampfli, G. M. (2012). The Altaids of Central Asia: a tectonic and evolutionary inn, atıve review. Earth-Science Reviews, 113(3-4), 303-341.

Windley, B. F., Alexeiev D., ‘iao, W., Kröner, A., \& Badarch, G. (2007). Tectonic models for accretion of the ren ral isian Orogenic Belt. Journal of the Geological Society, 164(1), 31-47.

Xiao, W., B. Windley, s. Sun, J. Li, B. Huang, C. Han, C. Yuan, M. Sun, and H. Chen (2015), A tale of amalgamation of three collage systems in the Permian-Middle Triassic in Central Asia: Oroclines, sutures and terminal accretion, Annual Review of Earth and Planetary Sciences, 43, 477-507

Xiao, W., Windley, B.F., Han, C., Liu, W., Wan, B., Zhang, J.E., Ao, S., Zhang, Z. and Song, D. (2018) Late Paleozoic to early Triassic multiple roll-back and oroclinal bending of the Mongolia collage in Central Asia. Earth-Science Reviews, 186, pp.94-128.

Yakubchuk, A. (2004). Architecture and mineral deposit settings of the Altaid orogenic collage: a revised model. Journal of Asian Earth Sciences, 23(5), 761-779.

Yakubchuk, A. (2008). Re-deciphering the tectonic jigsaw puzzle of northern Eurasia. Journal of Asian Earth Sciences, 32(2-4), 82-101.

Yakubchuk, A. (2017). Evolution of the Central Asian Orogenic Supercollage since late Neoproterozoic revised again. Gondwana Research, 47, 372-398. 
Yarmolyuk, V. V., Kudryashova, E. A., Kozlovsky, A. M., \& Savatenkov, V. M. (2007). Late Cretaceous-Early Cenozoic volcanism of Southern Mongolia: A trace of the South Khangai mantle hot spot. Journal of Volcanology and Seismology, 1(1), 1-27.

Zhang, J., Sun, M., Schulmann, K., Zhao, G., Wu, Q., Jiang, Y., Guy, A. \& Wang, Y. (2015). Distinct deformational history of two contrasting tectonic domains in the Chinese Altai: Their significance in understanding accretionary orogenic process. Journal of Structural Geology, $73,64-82$.

\section{Figure captions}

Fig. 1: A simplified regional geological map of the Mongol Hingan orocline (drawn after Parfenov et al., 2003). Colors represent the individual regionas 'nits of the Mongolian and Hingan orocline fold. The Precambrian continental blocks a e 1 arked by capital letters (B: Baydrag, TM: Tuva-Mongol, DB: Dzabkhan-Baydrag, F- Gr una, BJK: Burya-JiamusiKhanka, SG: South Gobi). The map of the CAOB is sh wn on the bottom right (modified after Han and Zhao, 2018) with indicated oroclines (rec. Kazakhstan orocline, blue: MongolHingan orocline).

Fig. 2: A simplified sketch of development of in - Mongolian orocline. (a) shows the Late Silurian subduction of the Paleo-Asian ocean un neath the East Junggar-Trans Altai Zone and the opening of a rift system. This is 1 'lov ${ }^{-e d}$ by the Carboniferous initialization of the Mongol-Okhotsk oceanic subduction ( $b$, ,ote that the continental blocks and the Mongol Altai Zone were welded together prior to th 'se two stages. Stages (c) and (d) show PermoTriassic oroclinal buckling induced $b$; the drift of the North China Craton towards the Siberian Craton and the compressio i $r_{i}$ remnants of the accretionary system after slab breakoff. The buckling caused by the $r \neg n v$ gence of the two cratons results in a development of the Mongolian and Hingan oro ines (the subject of this study). The cross-sections that are shown in these four stages are 1lustrative and non-scaled. The sketches are based on figures published in Xiao et al. (2015) and (2018). The abbreviations of the Precambrian continental blocks are the same as in Fig. 1

Fig. 3: The model setup o the oroclinal buckling experiments. A 3D model view at the model domain is shown in (a) which shows the pre-deformation folded geometry of the CRAW (the average value of the half amplitude and half wavelength are $5 \mathrm{~cm}$ and $15 \mathrm{~cm}$ respectively). The individual model layers with the specific material properties $\left(\rho\right.$ - densities $\left(\mathrm{g} \cdot \mathrm{cm}^{-3}\right)$ and $\eta$ - viscosities $(\mathrm{Pa} \cdot \mathrm{s})$ ) are illustrated at (b) with the corresponding strength profiles shown in (c). The model setup corresponds to the stage in the evolution of the structure shown in the Fig.2c.

Fig. 4: A topographic view of the experiment showing its evolution after $0,25,37$ and $50 \%$ shortening.

Fig. 5: Five sections cut perpendicular to the direction of shortening. The orientation map of the individual cross-sections of the sliced domain is situated at the top of the figure. The 
cross-sections display major structures and give the sense of material movement (arrows direction) in different parts of the whole domain.

Fig. 6: Six sections cut parallel to the shortening direction. The orientation map of the individual sections of the sliced domain is situated at the top of the figure. The cross-sections display major structures and give the sense of material movement (arrows direction) in different parts of the whole domain.

Fig. 7: The incremental evolution of the model domain. Three different stages of the shortening are shown on the left side with two lines for sectioning (red/yellow). The corresponding cross-sections on the right reveal the progressive development of major deformation features inside the model domain.

Fig. 8: The model surface analysis. For reconstruction of $\mathrm{m}$. teri 1 transfer at the surface we analyzed the displacement field calculated by PIVlab sof'wa "e. Panel (a) represents a shear strain rate where arrows correspond to the velocity fi sl' ar.d colors represent the second invariant of the deviatoric part of the strain-rate tensor (isovolumetric shear deformation). The divergence of the velocity field is shown in the : ane (b) where major anomalies situated in the MO and EJTA part are related to the developmer. of pop-ups (positive divergence) and pop-downs (negative divergence). A digital ele ra ion model (DEM) is shown in panel (c). Narrow elevated parts in the EJTA and MO c rre spond to pop-ups. The velocity profiles across line A-B (for the various shorter. $\mathrm{g}$ tages shown in panel (b)) are displayed in diagram (d). These profiles show a tra. sit' on of the model dynamics from an indentationsimilar evolution (blue curve) to a homogen sus thickening evolution (red curve).

Fig. 9: A block diagram of the modt!', i iner dynamics. At the top is shown the colour map of the vorticity that reveals a clockirisu rotation of the orocline inflection and counterclockwise rotation of the orocline outer $1 \mathrm{~m}$. The black arrows correspond to material flow from the indenter side to the backstop ' $\mathrm{wh}^{\cdot}{ }^{1}$ e the red arrows show a decreasing vorticity in the material transfer from the surface in th: basement. The red dashed curve represents the interface between the MO and the ${ }^{\top}$ A subdomains, which coincides with the CRAW.

Figure 10: Gravity dat: - nowing the presence of East Junggar-Trans Altai Zone dense crust beneath the Mongol Altai Zone at the boundary of the East Junggar and the Chinese Altai regional units. A. Location of the gravity map and the modelling profile with respect to the hinge of the Mongolian orocline. B. Complete Bouguer anomaly map and location of the modelling profile. The color scale of the gravity anomalies is linear. The thick white line represents the surface contact between the East Junggar-Trans Altai Zone and the Mongol Altai Zone crust C. 2D forward model along profile A-A' cross-cutting the Mongol Altai Zone and the East Junggar-Trans Altai Zone boundary. The observed and calculated gravity data are shown in the upper panel. The lower panel shows the 2D structure of the crust in northwestern China: 1) Underthrusting of the dense East Junggar-Trans Altai crust beneath the Mongol Altai Zone, 2) extrusion of Permian granulites south of Altai city and 3) exhumation of the Devonian granite-migmatite dome in the central part of the Mongol Altai Zone. Geophysical model (Fig. 10c) is modified after Guy et al., (in review) where the geophysical modeling procedure and details of gravity data are explained. 
Figure 11: Gravity data showing the linear gravity highs in the East Junggar-Trans Altai upper crust in SW Mongolia. A. Location of the gravity map and the modelling profile crosscutting the core of the Hingan orocline. B. Isostatic residual gravity map and location of the profile. The color scale of the gravity anomalies is linear. C. 2D forward model along profile B-B' cross-cutting the Mongol Altai Zone, the East Junggar-Trans Altai Zone and the South Gobi Zone in southern Mongolia. The observed and calculated gravity data are shown in the upper panel. The second panel shows the global structure of the crust in southern Mongolia: 1) development of three $20 \mathrm{~km}$ deep vertical tabular upper crustal zones marked by high density penetrating into lower density lower crust, 2) intermediate density lower crust beneath the Mongol Altai and East Junggar-Trans Altai zones (representing the relaminant), 3) minor underthrusting of the East Junggar-Trans Altai Zone strong and dense upper crust beneath gently thickened Mongol Altai Zone upper-middle crust. Geophysical model (Fig. 11c) is modified after Guy et al., (in review) where the geophysical modeling procedure and details of gravity data are explained.

Fig. 12: (a) schematized 3D model of the Mongolian Hino $\cdot$ oroclinal system combining map view with walls perpendicular and parallel to he axial plane of oroclines both experimental results and geological data from the ste liea region of Mongolia and China. The position of the main tectonic zones (Mongol Okhots' $\backsim$ ne, Precambrain continents, Mongol Altai Zone and East Junggar-Trans Altai Zor.e, are shown together with modeled MO, CRAW and EJTA subdomains. (b) sections a $z_{r}$ :s he schematized 3D model perpendicular to the axial planes of oroclines show: 1) - hu nation of the MO mantle material (dark red) beneath the core of the Mongolian oroci ne , central block), 2) general redistribution of EJTA mantle beneath the hinge of Mongolian or line from the adjacent rear part of the Hingan orocline (light red), 3) underthrusting \& EJTA crust beneath the CRAW in the hinge of the Mongolian orocline and 4) pop dow a wctures affecting the EJTA subdomain in the core of the Hingan orocline.

\section{Table captions}

Tab. 1: The model rheological $\mathrm{r}$ rameters and scaling ratios.

Tab. 2: The scaling mod 1 p.rameters - Ramberg numbers. 
OK co-designed and prepared all models including performing of the photogrammetry and velocimetry, analyzed the results (kinematic and dynamic behavior of the model), prepared figures 2-9 and 12, wrote the first draft of the manuscript and contributed to the general discussion about interpretations in a frame of the CAOB. OL co-designed model, contributed to the manuscript preparation including drawing of the Figure 1 and consultation of the Fig. 2, 8 and 12, involved ideas to broad discussion of the model results in a frame of the field observations from the CAOB. KS improved texts of the manuscript, in particular Introduction and Discussion, consulted preparation of the Fig. 1, 2, 10, 11 and 12, brought new ideas to the Discussion part and correlated the results with the field observations from the CAOB. DG co-designed the model, consulted the rheological and kinematical aspects and improved final version of the manuscript. AG involved geophysical observations, prepared Fig. 10 and 11, contributed to discussion part and improvement of the last version of the manuscript. JC provided the grammar correction of the manuscript and contributed to discussion. WX contributed to discussion of the results in frame of the CAOB - nd helped with final reading of the manuscript. 
We declare that the submitted work was carried without the presence of any personal, professional or financial relationships that could potentially be construed as a conflict of interest. 
- Oroclinal buckling model of a vertical belt separating horizontally stratified domains

- Early buckling stage shows a characteristic of indentation tectonics

- Orocline amplification causes a large-scale vortex flow around an inflection line 


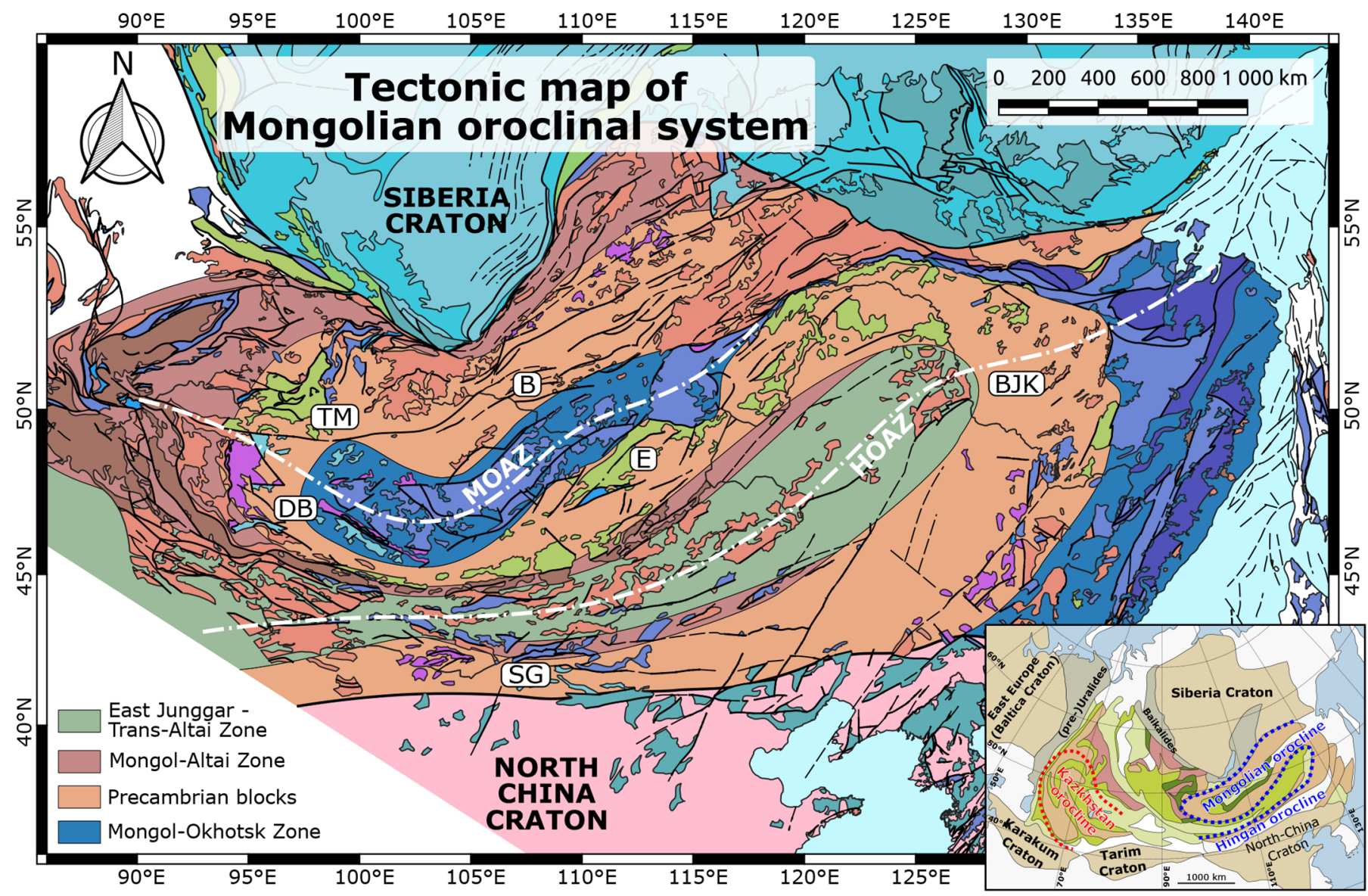

Figure 1 


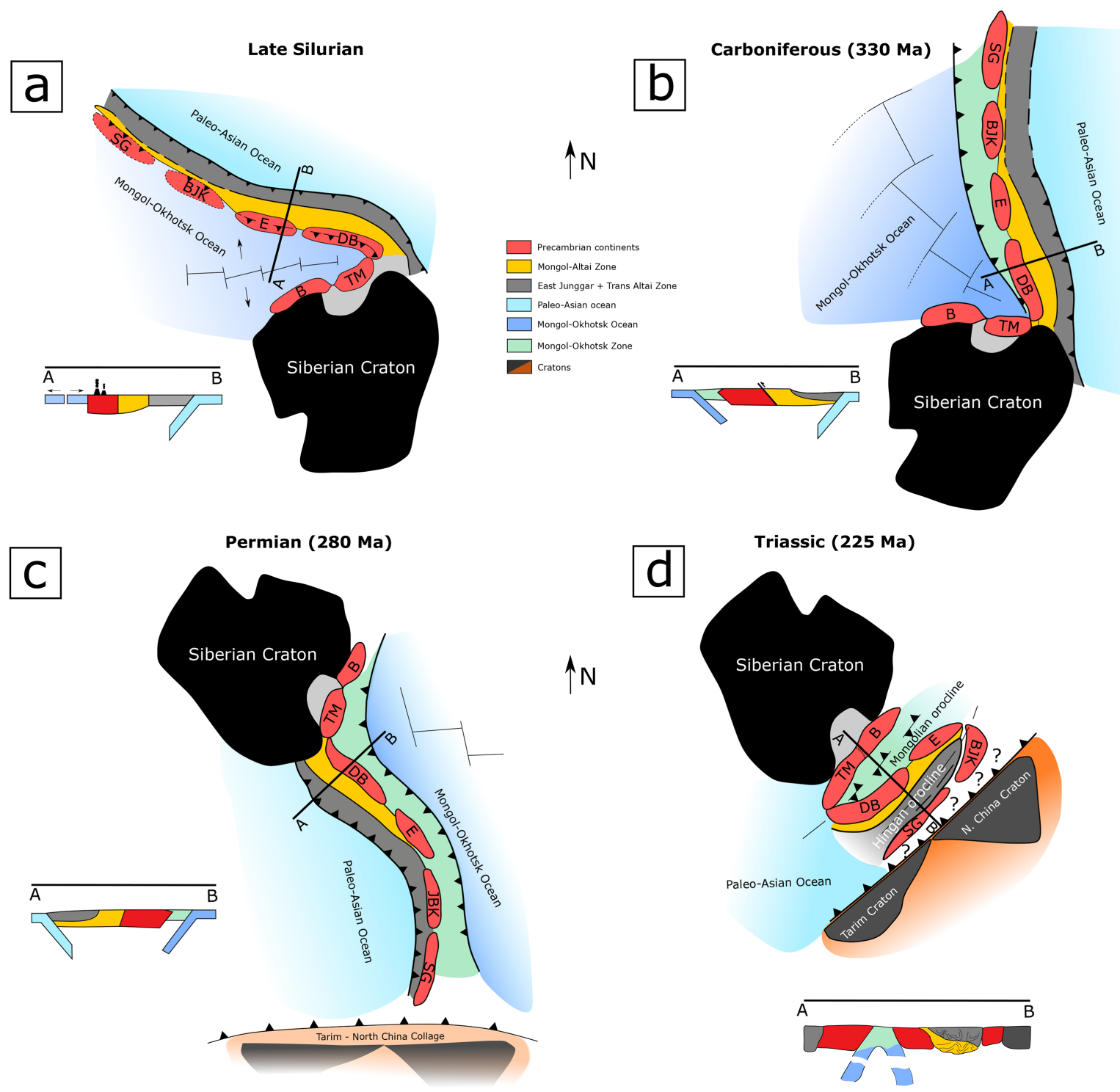

Figure 2 
a)

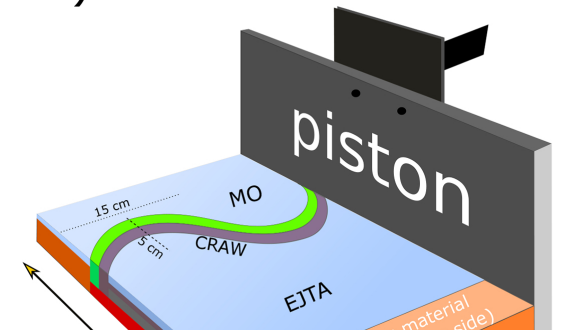

.

D b)

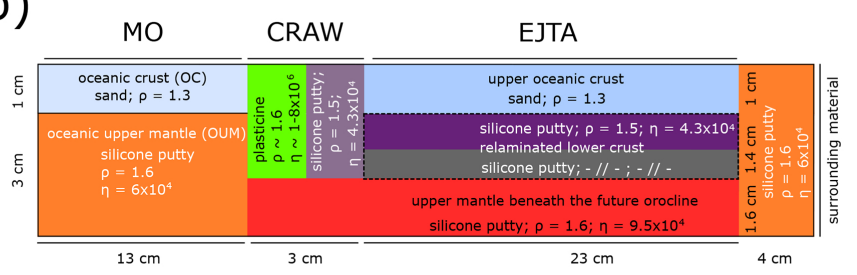

c)

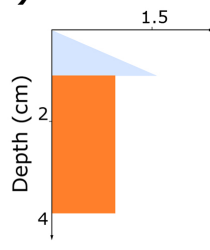

$\log \left[\sigma_{1}-\sigma_{3}\right](\mathrm{Pa})$

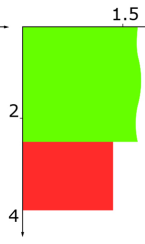

1.5

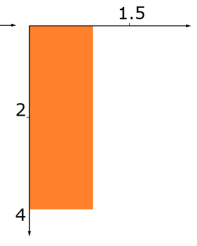

Figure 3 
Model domain evolution - topography view

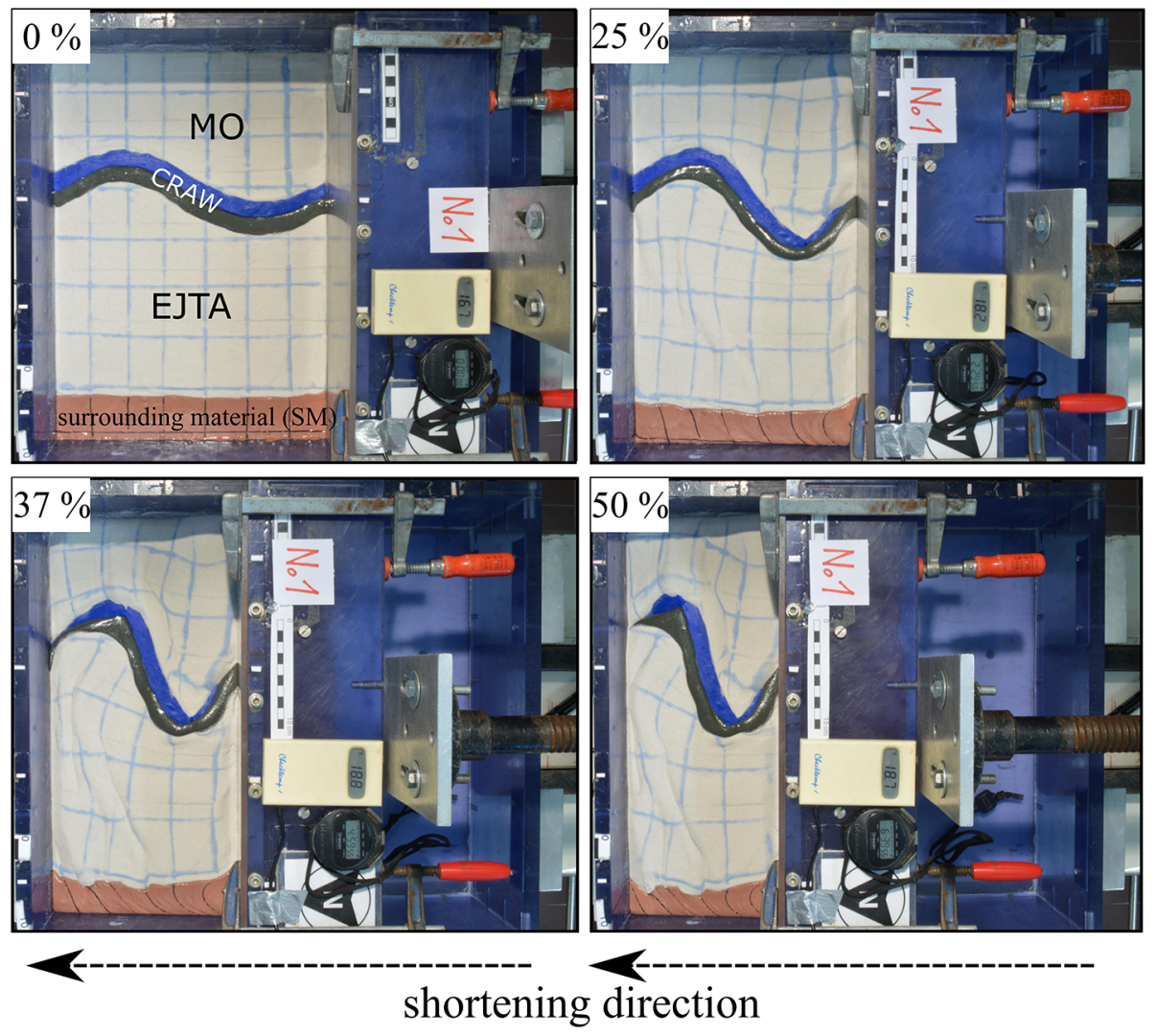

Figure 4 
piston side
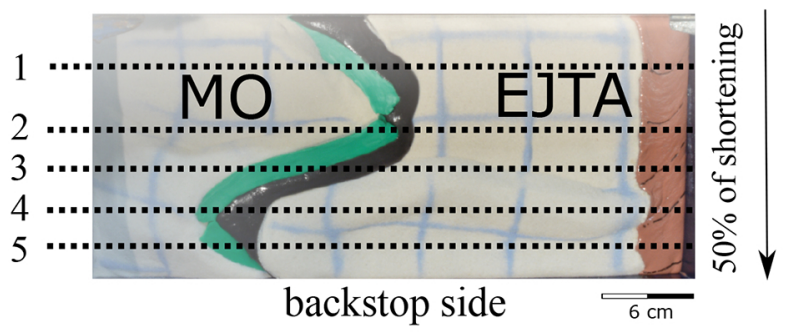

upper crust

CRAW

EJTA middle-lower crust (relam.)

EJTA + CRAW upper mantle

MO upper mantle

/ surrounding material

situation beneath removed upper crust (sand layer)

1

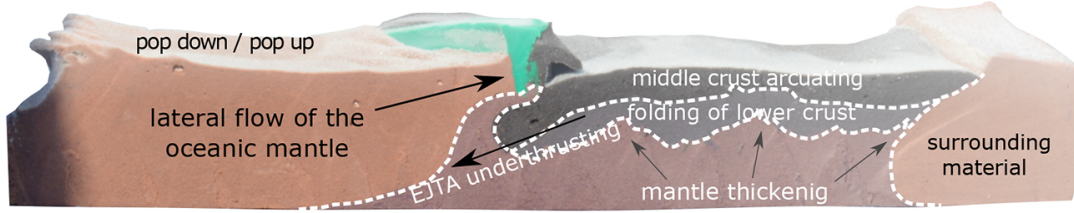

2

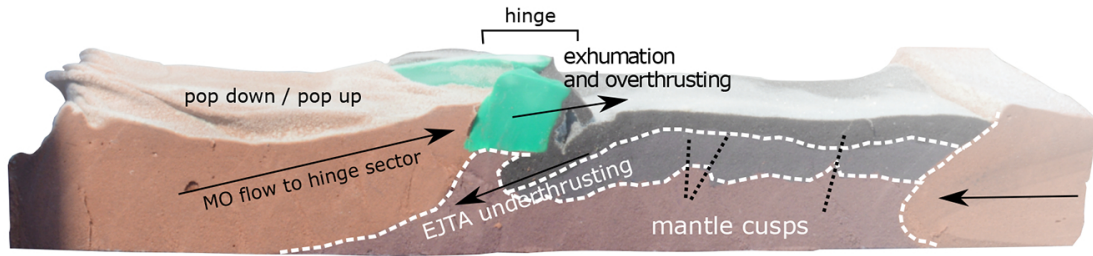

3

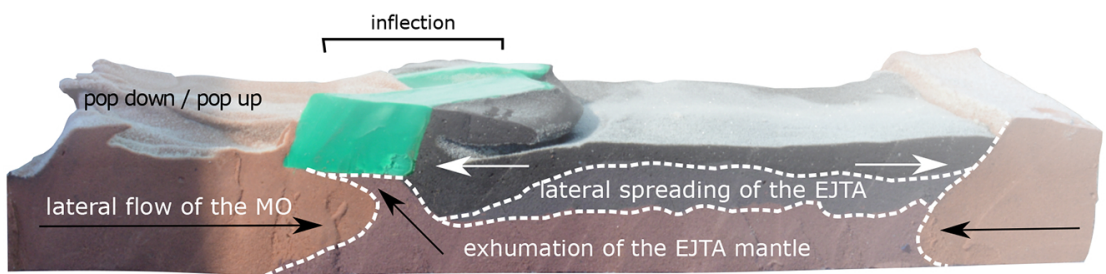

4
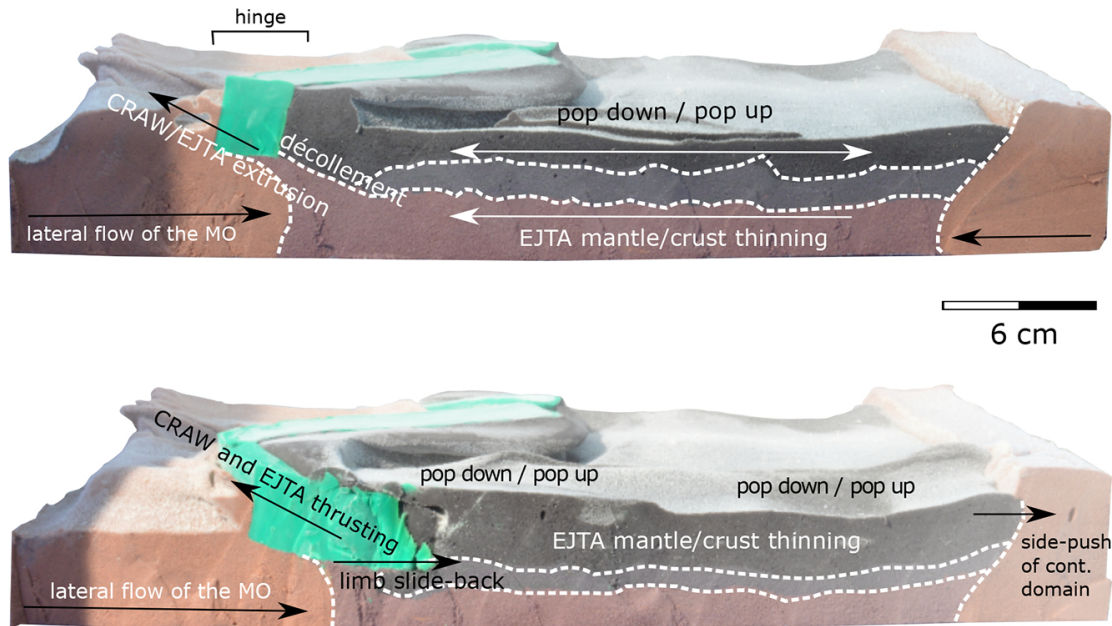


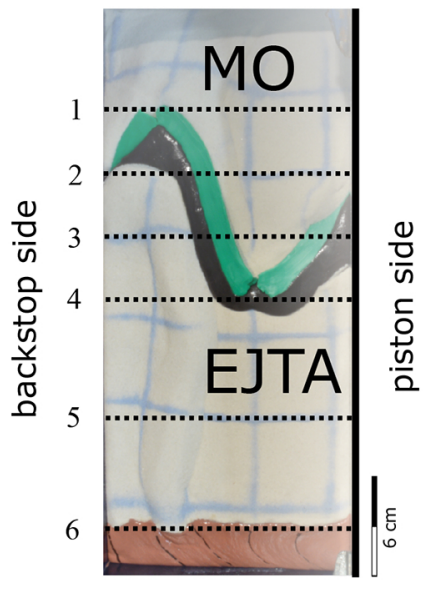

$50 \%$ of shortening

1

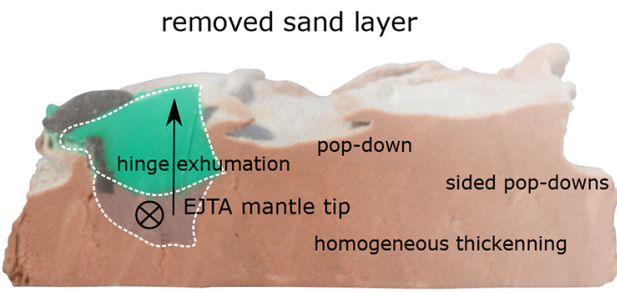

2
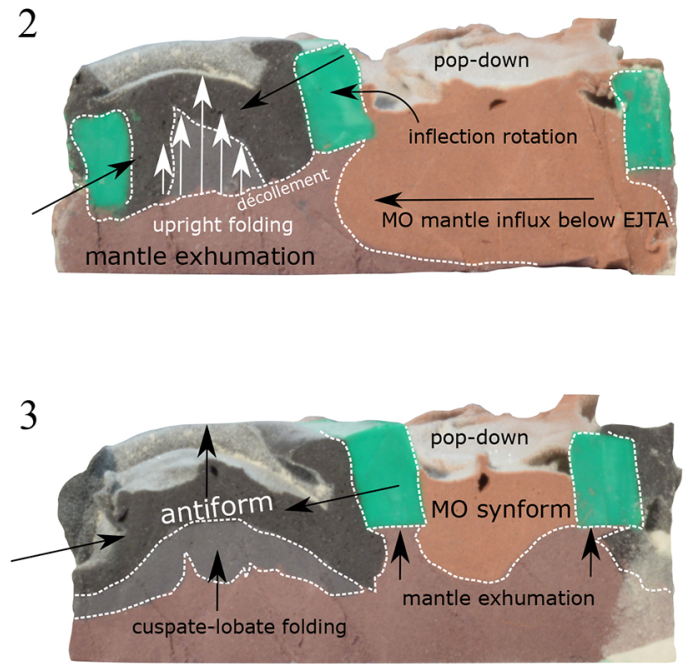

upper crust

\section{CRAW}

EJTA middle-lower crust (relam.)

EJTA + CRAW upper mantle

MO upper mantle

/ surrounding material
4

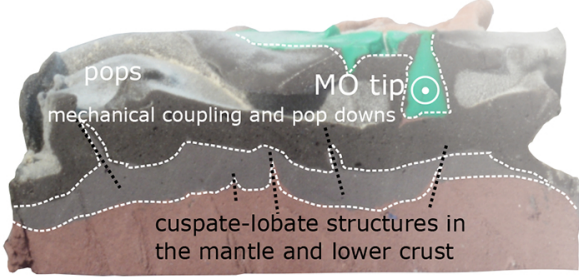

5

$6 \mathrm{~cm}$

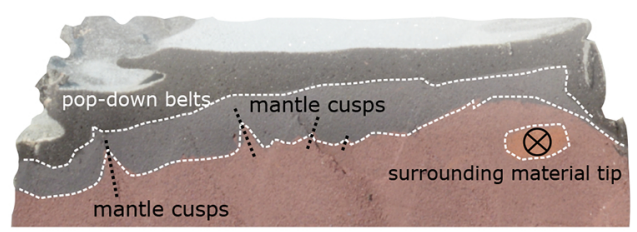

6

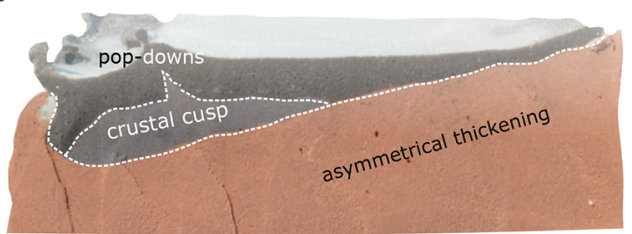



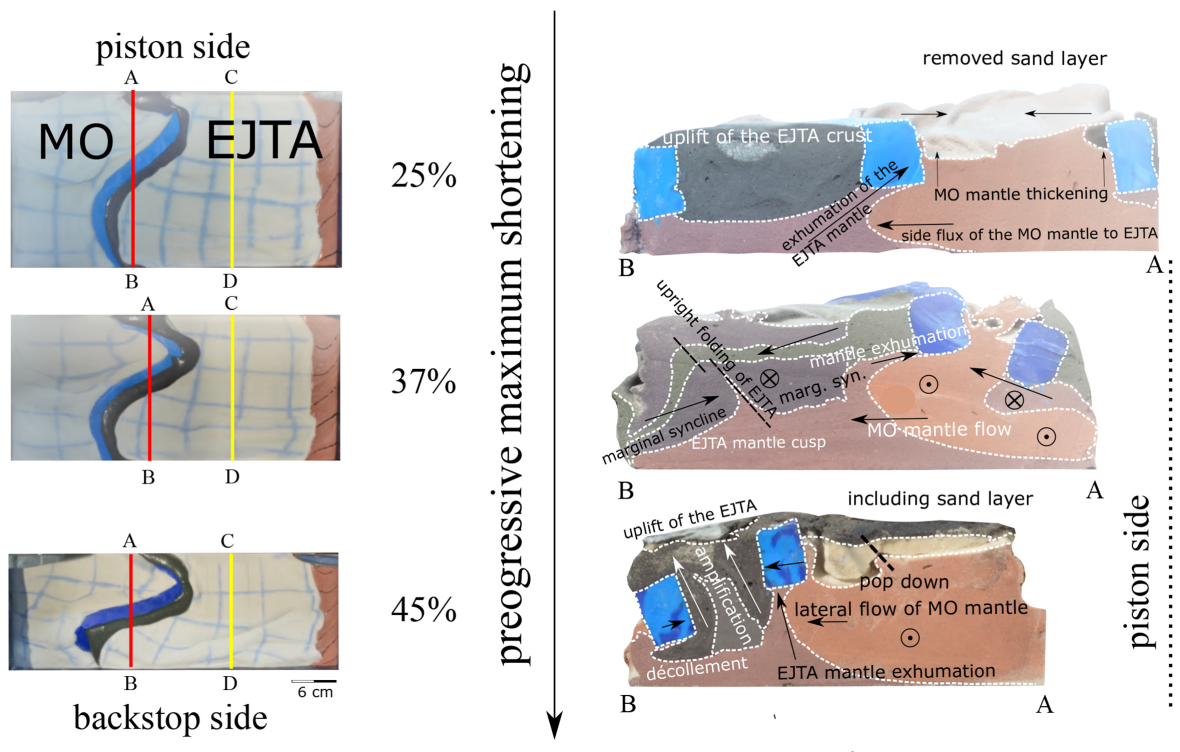

removed sand layer

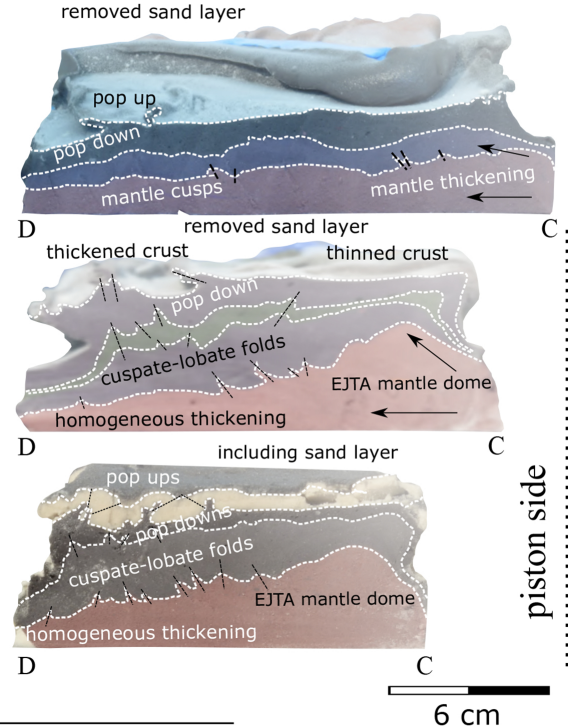

shortening direction

upper crust

CRAW

EJTA middle-lower crust (relam.)
EJTA + CRAW upper mantle

MO upper mantle

/ surrounding material $\odot$ $\otimes$ flow in lateral direction

Figure 7 


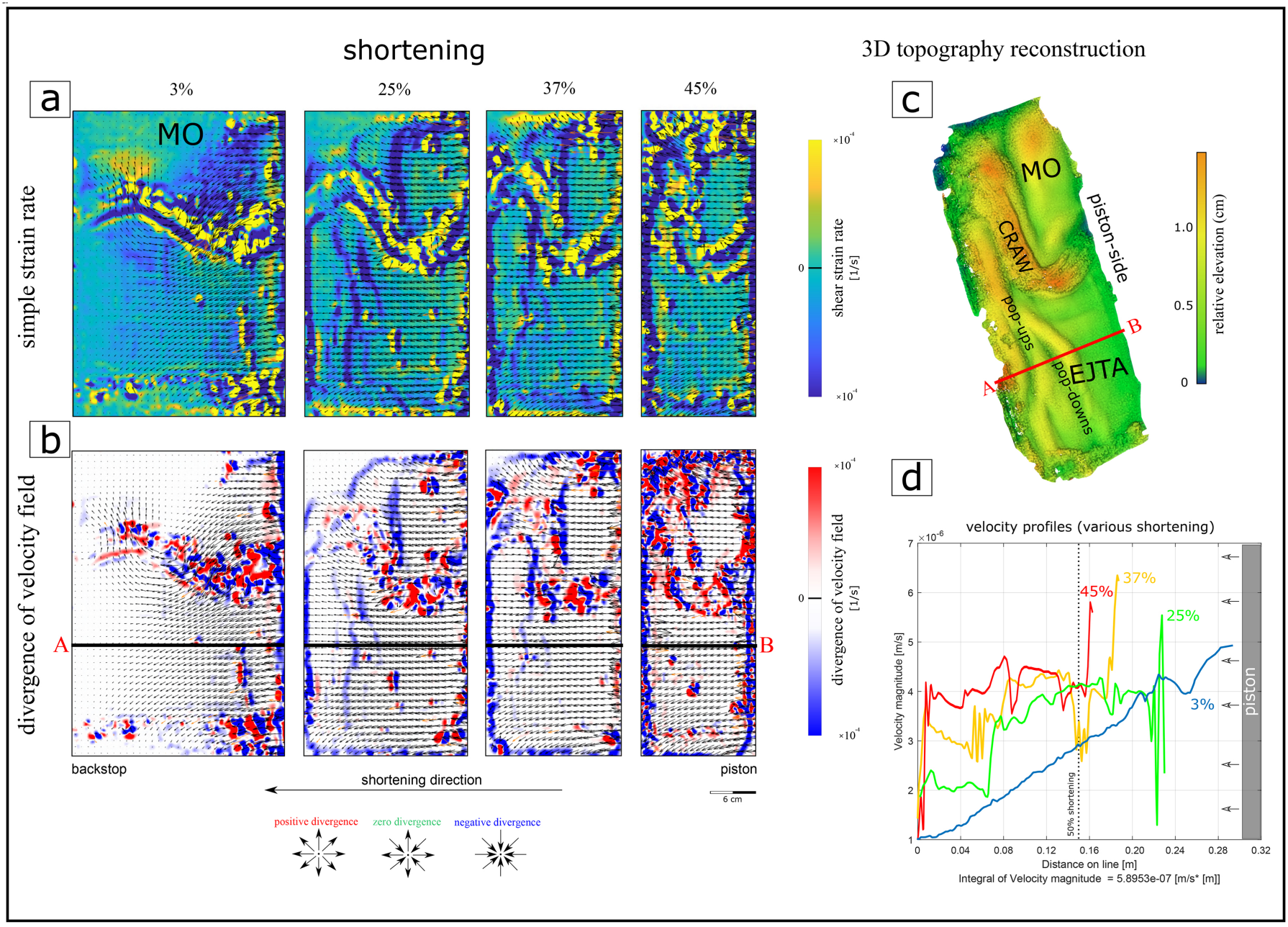

Figure 8 


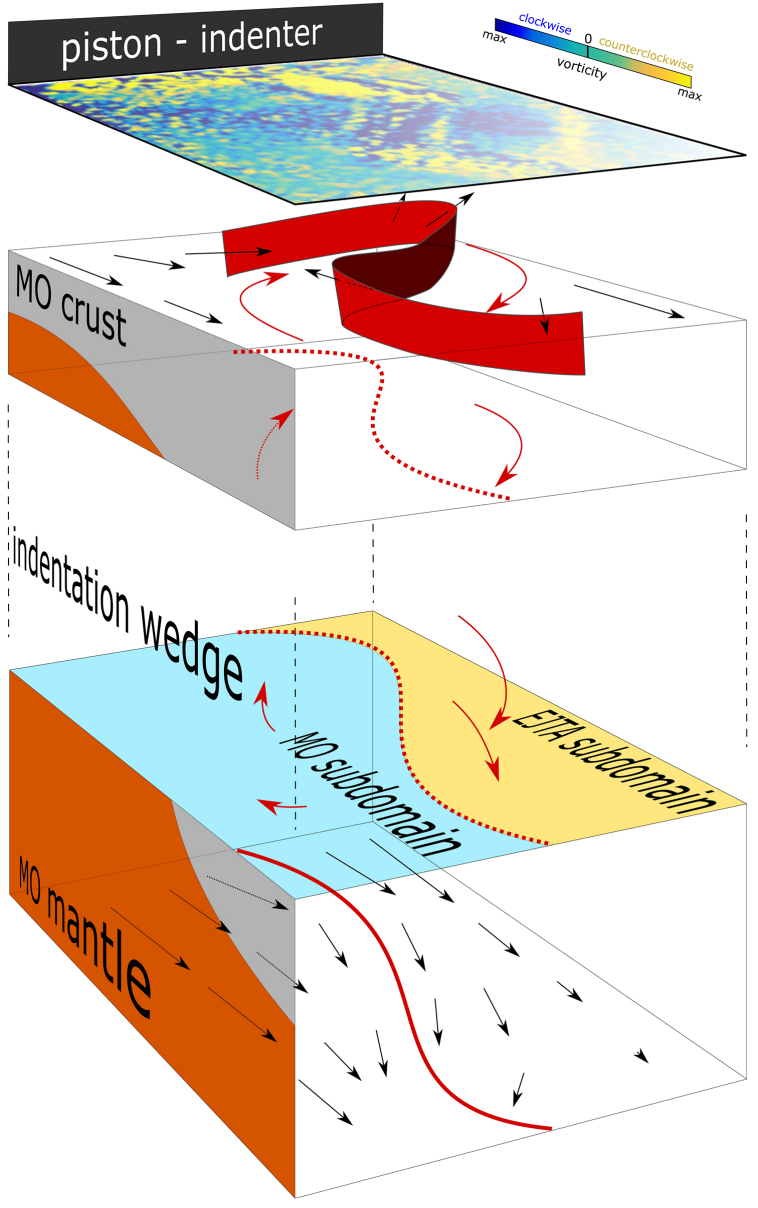

Figure 9 


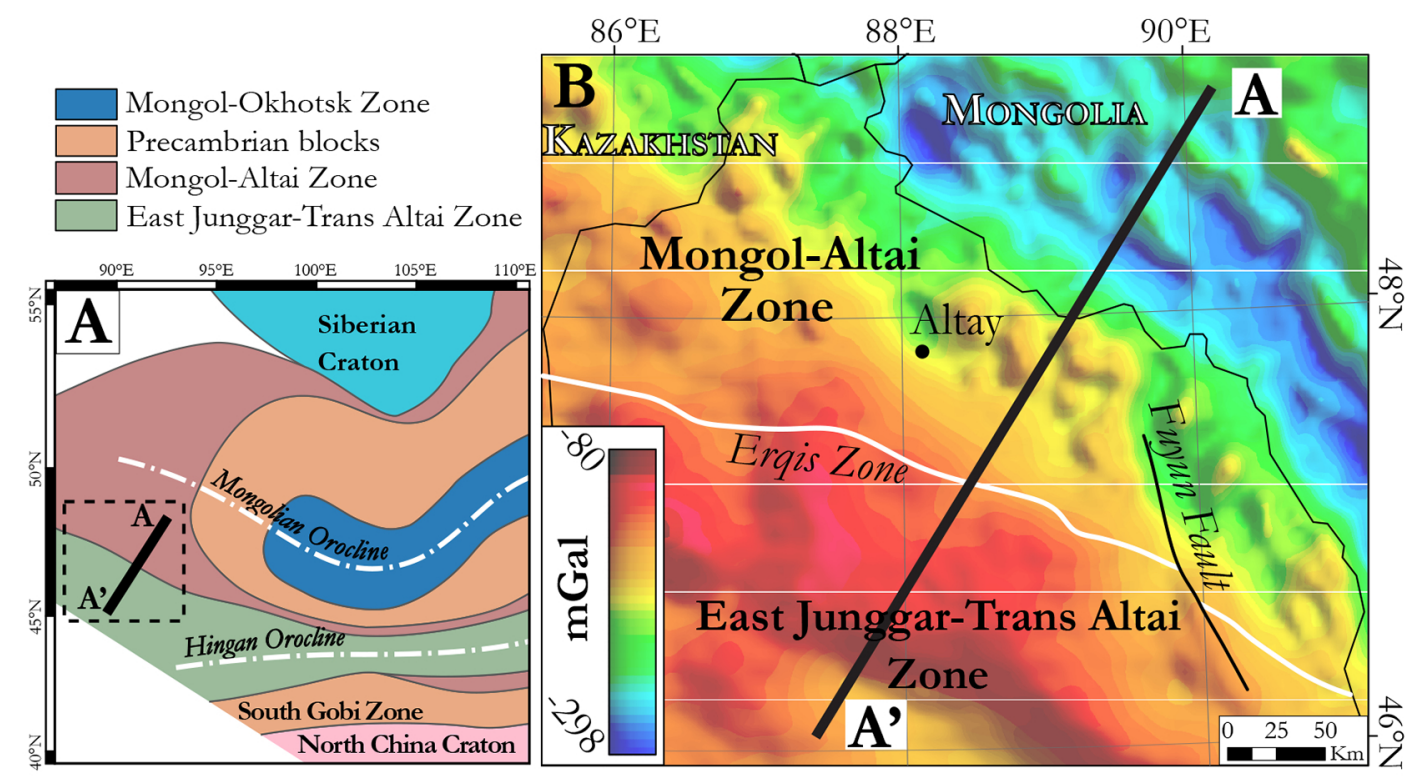

C A-A' profile - Complete Bouguer anomalies

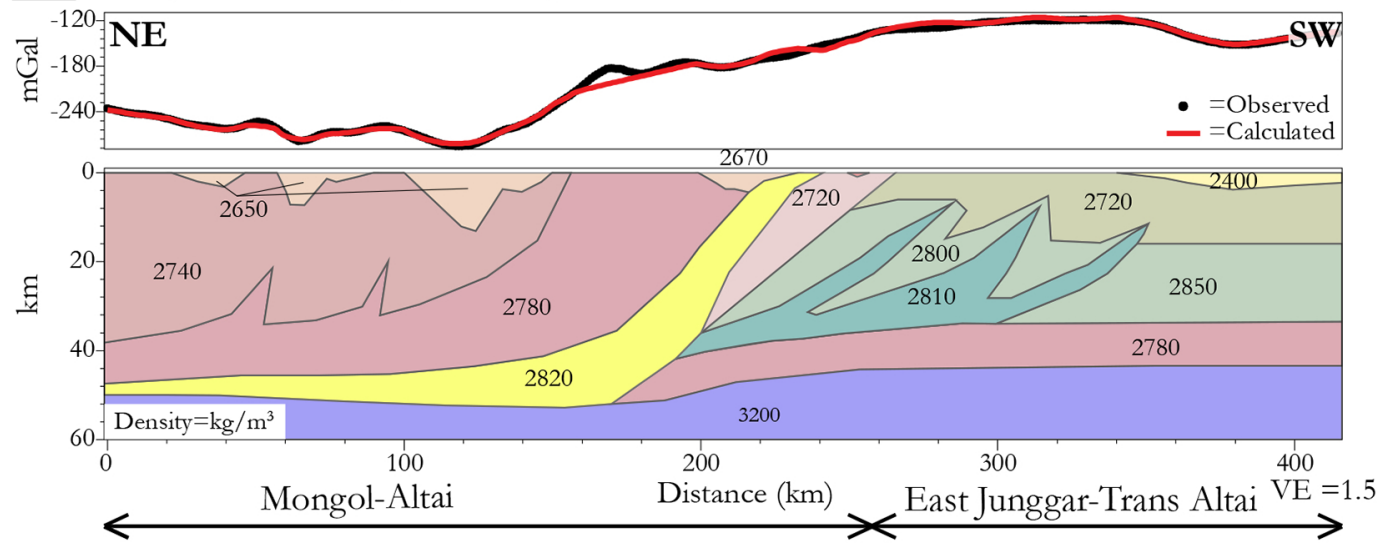

\section{Mongol-Altai Zone}

$\square$

Permian granulites

Devonian sed.

Ordovician vol.-sed.
East Junggar-Trans Altai Zone

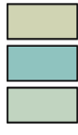

Devonian-Carboniferous vol.-sed.

Ophiolites

Lower crust

Homogeneous lower crust

derived from Mongol-Altai Zone $\square$ Cenozoic basins Mantle 
$\square$ Mongol-Okhotsk Zone

Precambrian blocks

Mongol-Altai Zone

East Junggar-Trans Altai Zone

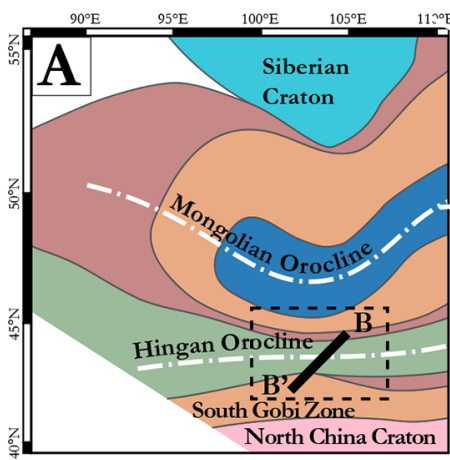

$98^{\circ} \mathrm{E} \quad 100^{\circ} \mathrm{E} \quad 102^{\circ} \mathrm{E} \quad 104^{\circ} \mathrm{E} \quad 106^{\circ} \mathrm{E}$
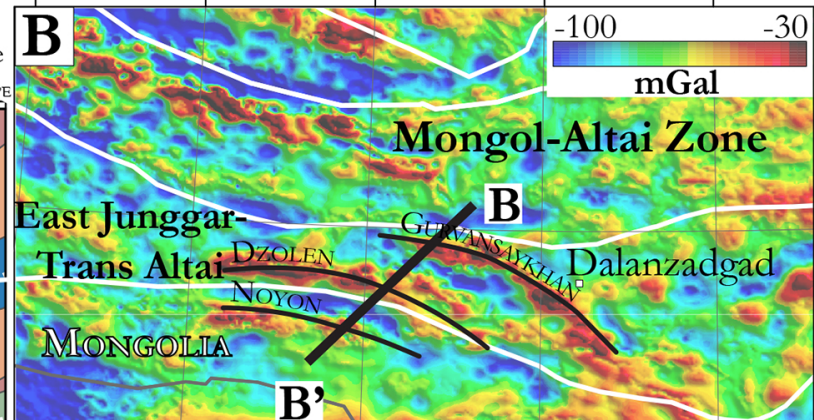

South Gobi Zone

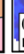

C B-B' profile - Complete Bouguer anomalies
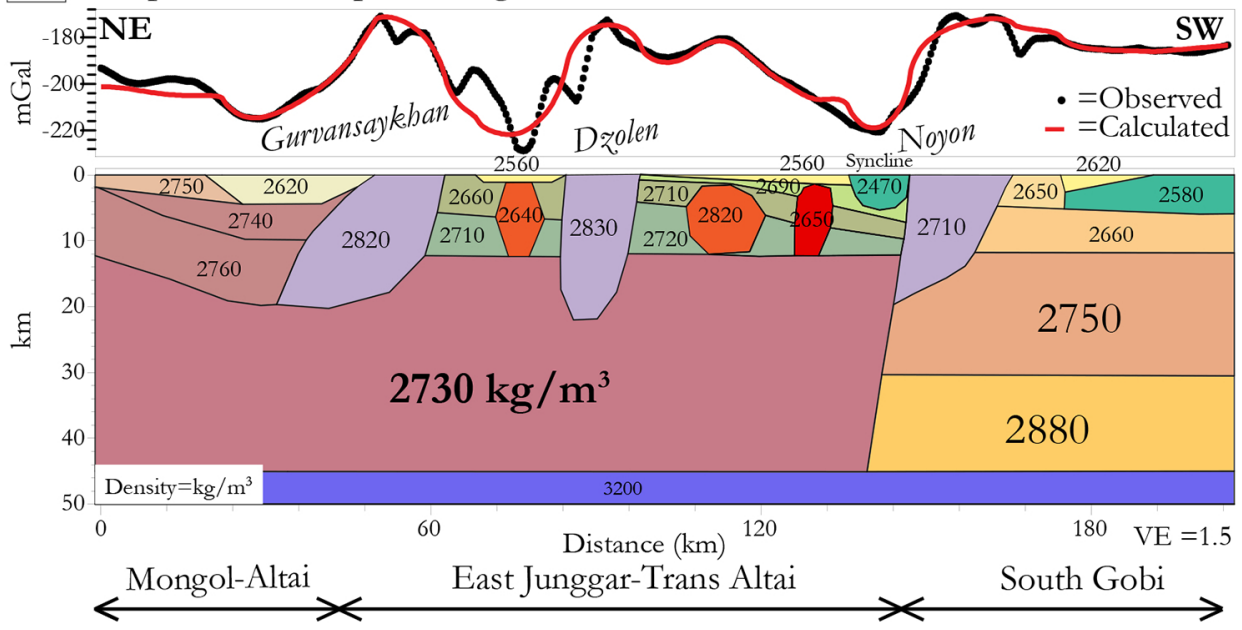

Figure 11

\section{Mongol-Altai Zone}

$\underset{+}{+}$

Cretaceous sed.

Devonian sed.

Ordovician vol.-sed.

East Junggar-Trans Altai Zone

$\square$ Triassic sed.

Permian vol.-sed.

Devonian-Carboniferous vol.-sed.

Devonian vol.-sed.

\section{South Gobi Zone}

$\square$ Triassic sed.

$\square$ early Permian sed.

late Ordovician-

early Silurian sed.

Middle crust

Lower crust

Devonian granitoids

Carboniferous-Permian granitoids

Cenozoic basins

High-strain zones, pop-downs (Metamorphic/Ultramafic rocks)

Homogeneous lower crust derived from Mongol-Altai Zone 


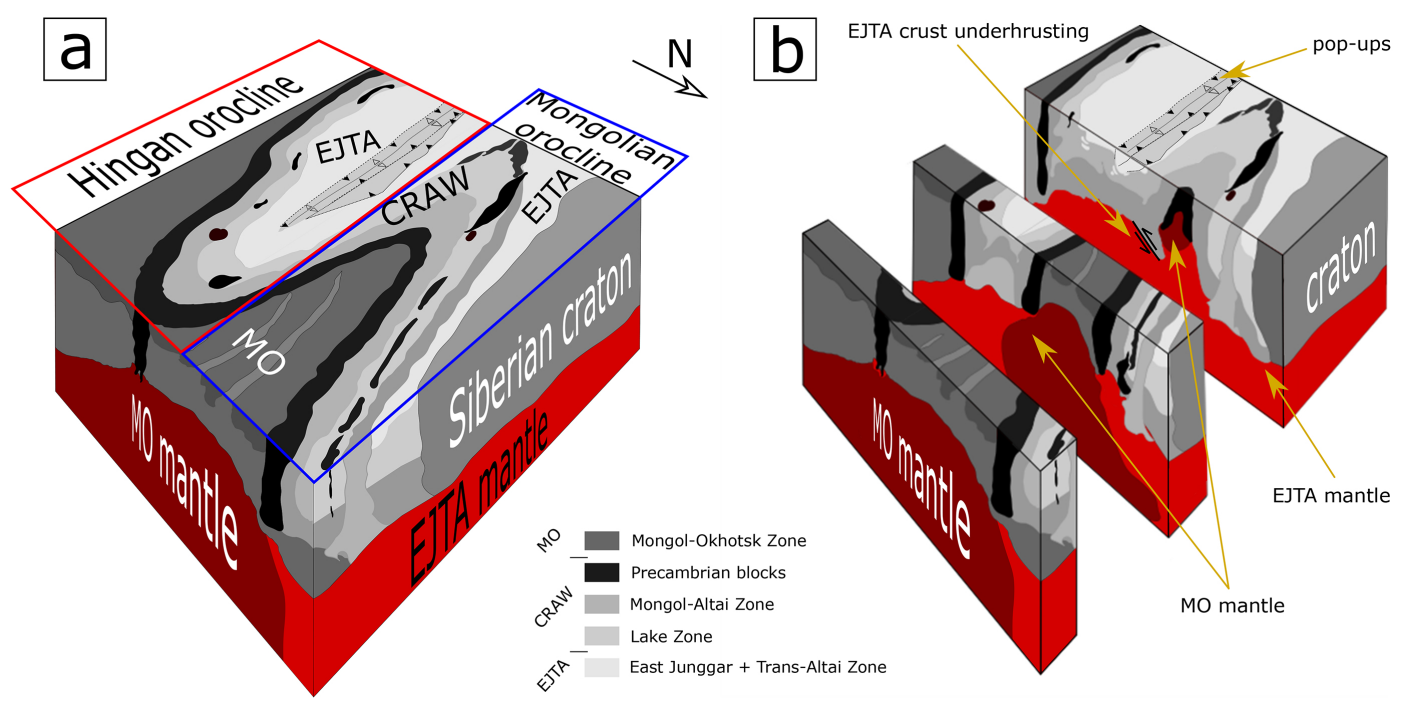

Figure 12 